のにあ枯はにイ社ししこ原す

若さり渴ずおツ会てての因べ凬

手れ、しでけェ学いき運とき知

のなも貧あるル打るた動し変の

社けは困るそはよ。もはて化よ

会れや化がのつびこの、はのう

学ば、し、創ぎ社ので一、兆に

者な外て現始の全連あ九いしいじ

たら部し在者よ学動り、六わがこめ

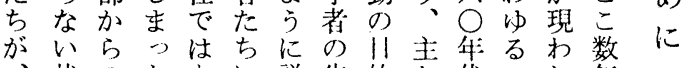

状のたあに説皆的之代子れ年:

社況新学ま占明発とし末来ラての

会にら開りつしに古て䏹デきあ

学あしのにててある若にイてい

のるいひ制社いると乎、カいた

基と活と度会る。このアルるに

本心力化会るころ社 邓社。

的光ににさ柋司は念り会こア

なそよな機社点、塕力学のメ

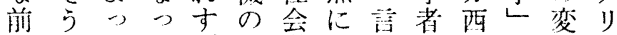

提でててき科学つうや海運化力

やあ断して学はい立大壯動を社

方る続ましと元てで学をがす会

向。的”ま多来、も院中西た学

のまにてつな公な非心げらに

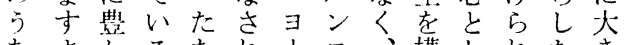

ちま爫るたれ、ス、構しれたき

の寸なよめてロ・既成てよ话な

若多むうにききだ成員台う接注

は

G

$\mathrm{H}$

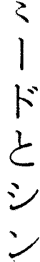

术

リ

ツ

ク

イ

れくにをら的しとこっとつちどの

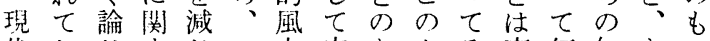

代しじすじ一土晏あよそ何知きの

ア朱らるて九の全いうの実を識わに

メっれ、五変かだな新でもをめた

リてるあての化つの”し市く政てい

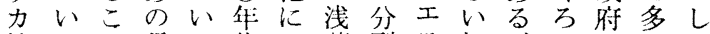

社ると垃る代よ薄裂不担がんやくて

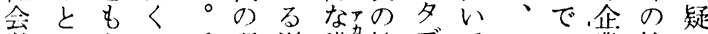

学いなてパ理影講驾払ブ手しい策社い

の) えくど、論響壇”大りをかるに会の

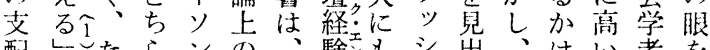

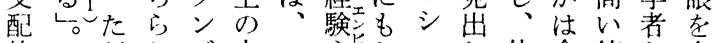

的たかで大い主监か二し他全值た向

理社とのき義妾かメは方く段ちけ

論会い理なだでわンじで頓でがる

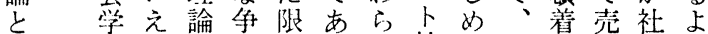

し史ばと点らるず社て社しり会ら

ての不機やれ。、会い会な、杢に

大フ毛能論たこ社学る学いそ学な

きアな主孙もの会“このとれのっ

な 1 論義はのよ斈とと批いら専て

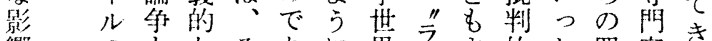

響のもなそあに界 ま゙ま的た買家き

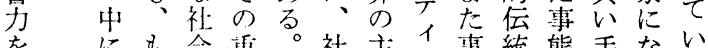

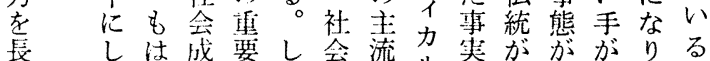

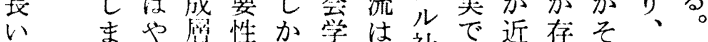

あい熱のやしの依社あ代壬れ自な

いこつ理関な政然会るにるに分る

だまぽ論心が治と学るなるるよたは 
個論のであをれのクるわ二価つ社頭なイね鹪関こか行 個を兄ら展シのれケ值と会し影力こ機しとけ使

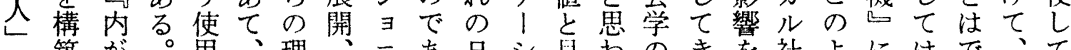

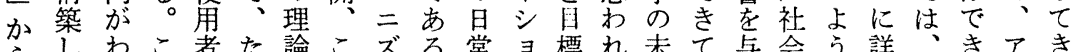

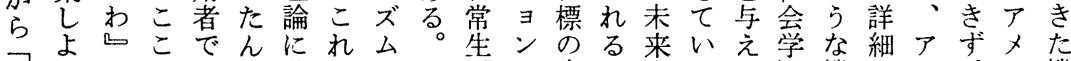
社らかにもな共ら、ェ活の奏ひにるるし機でル、リ機 会とら貫ある通が現スの佰とと。この能包ヴよか能

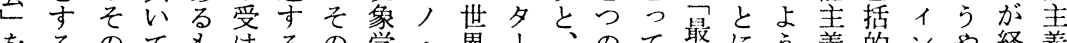
をるのてをけるの学・界、忖るて聚にう義的ンや経義 説思主いの手姿よ、ソののそ傾、近なに理なくく験理 明想体るとな勢う知シ構をの向私科る派論分 $\mathrm{W}$ 淍し論 し的性のしいはな識才造めよがに犁と手の析・落たも よ努をはてし、社社口にざう存は学思で调がグ化政

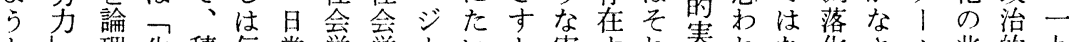

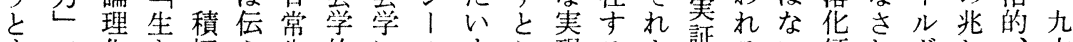
寸で化き極え生的にのすこ現るよ証るい傾れドし 六 るあした的手活態対勃るろの。り主、が向てナを経 発り、具なでで度す興関のみすも義いいとい1鼻済年 想、こ体人はののる、心地をなは唇く社並るのせ的代 でそれ的開な諸広新シが道可わる開つ会行。は变後 あれをな像い個㲸たン序な能ちか開か学し 迫じ化半 るは根諸を社人ななボ々䦔に、に真ののててりめのか 。底個描会の証関りにいすみ大简今、影ら 同換に人心構相明心ッ高をるずき间ら後いるい蠁七 時言据のて造互で、クま伴よかな引しのわ西る在○

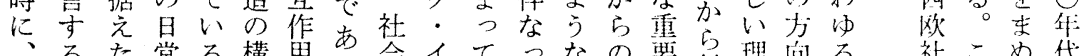

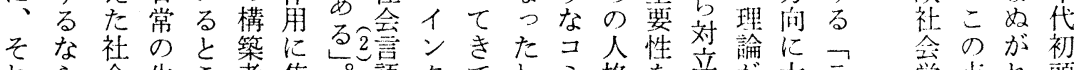

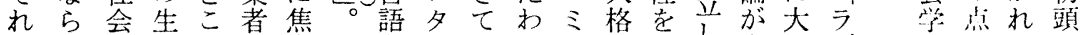
は、理活乃で点こ学ラいれュ的もし台きデののにる

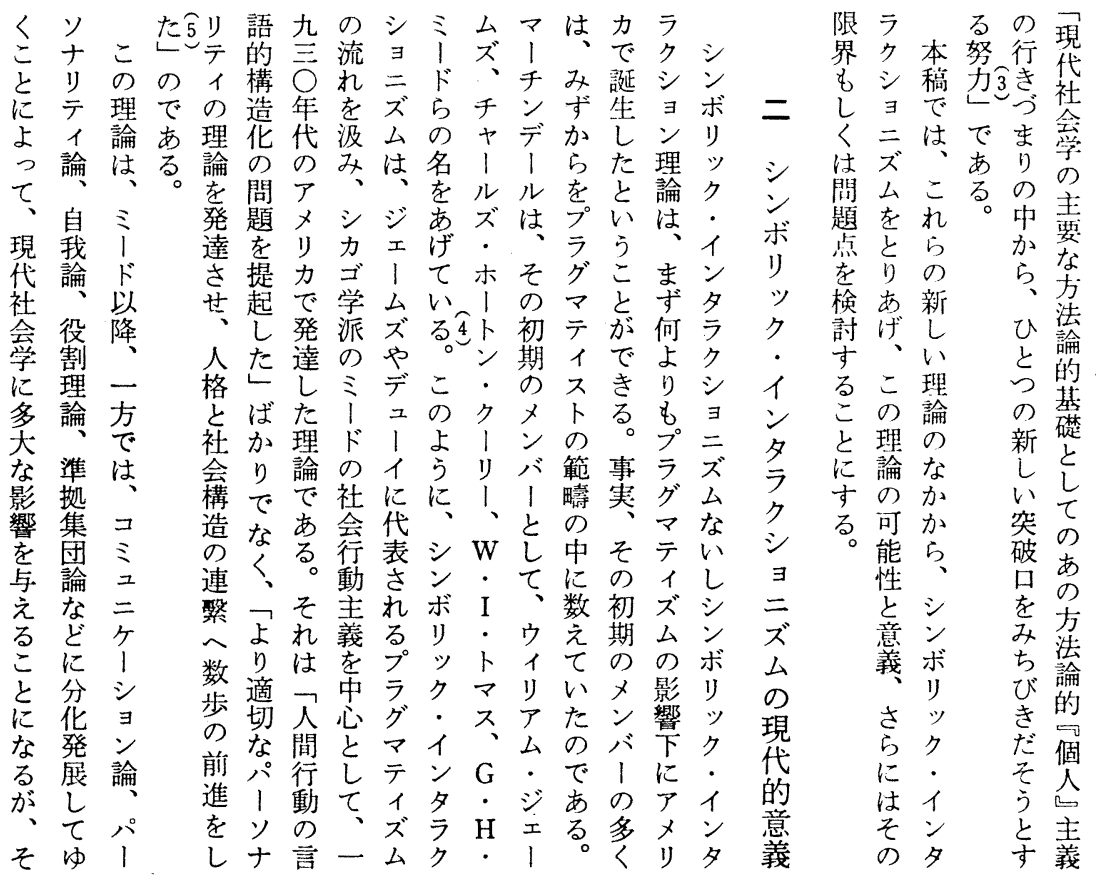




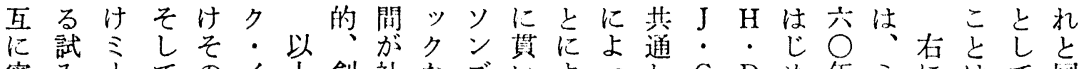
密み「てのイ上創社なズいようし G D 作ミに庄て同 接|ドそ機ン見造会行にてってて・・る代述ほの洔 に理れ械夕て的に為代いて拡兒マダ。にドべとアに かを論と論 ラき側㗢に表る、荍らニン主は以たんイ他 ら、に同的クた而きつさの統しれスカたい降よどデ方

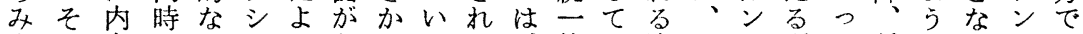

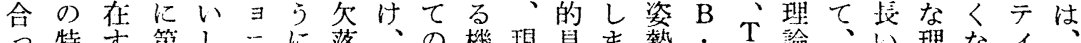

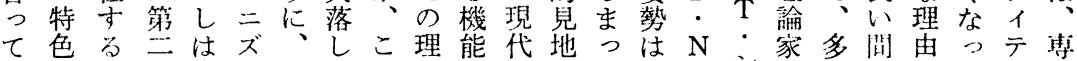

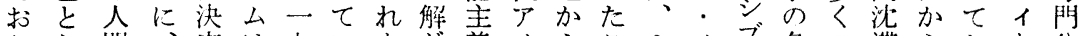

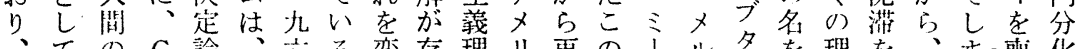

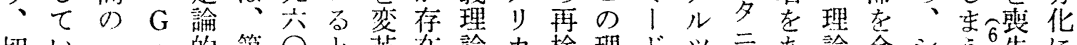
切

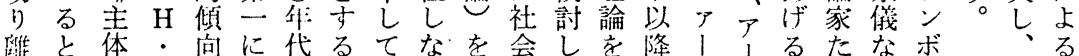

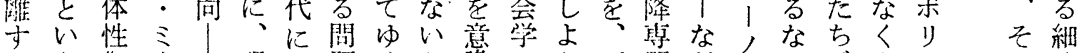
こえ“1現は題くと識のう再門どルらがさッの分

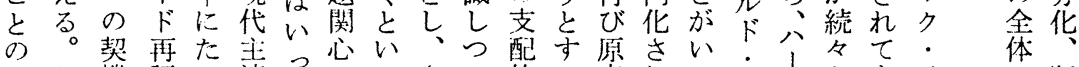
でこ機評い流つでっさつ的る点れる方卆ときイにに断 きれを仙す派てあたら、理とに、。詇たンお片 なら掘のる社かる人にそ論こま特こズ、文の名い化

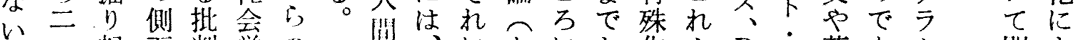
むつ起面判学の 行、にとにた化ら $\mathrm{R}$ ブ著あク閣よ も

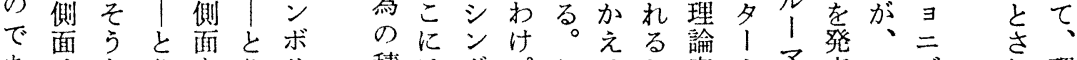

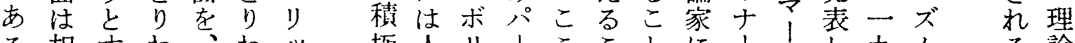

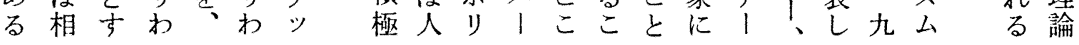

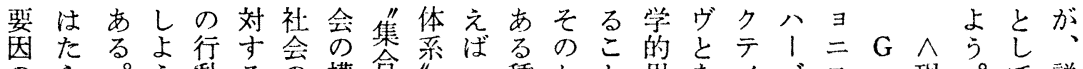
のら。う動るの構拿“、へ種かと思をイバス. 現。て説 あく人と娍成表”かのわ各考詨ヴ|卜 $\mathrm{H}$ 代八明

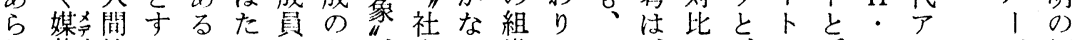
わ体社るいらでな”、会ら織にま、ささ、・㭔ミメ便

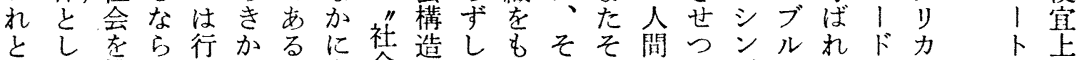

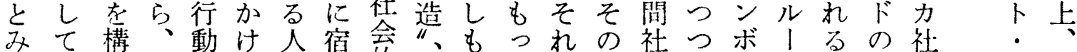

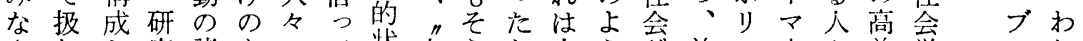

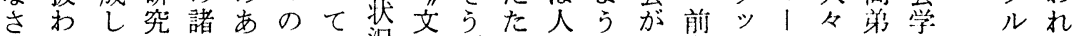

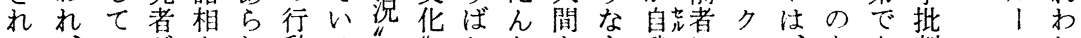

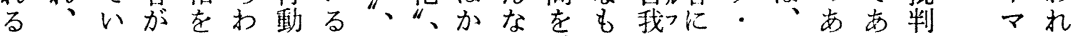

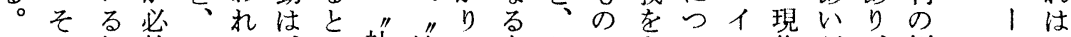
この個然こで、み社地と有かともいン代だ、側のつ のよ人的れあこな会位は機れしつてタアに面所ぎ ようはにらるれさ的“、限体のてた次ラメあまり説に

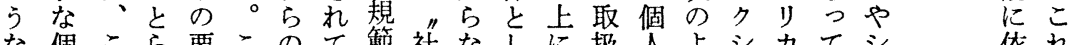
な個こら要このて範社なしに扱人よシ力てシ 方依れ ア人れざ因れ諸い”、会いて働うかうョ社長ンン拠ら プのらるのは要る゙的が想くこらに二会老ボ。しの

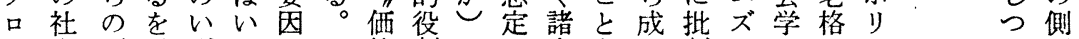

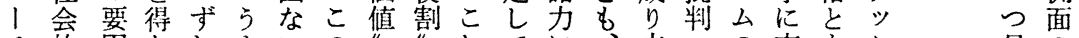
于的因なれまいの“”、机てに立しの支もク見の な行がいかでし想な施い対ほうてパ配い・各 い為そ論にも諸定ど漗諸るしとていは 的うイイ 々 しはこ理よな力にと慣力。てんいるるな 視こを的っくのよい“、注概反どる。ペパきタる

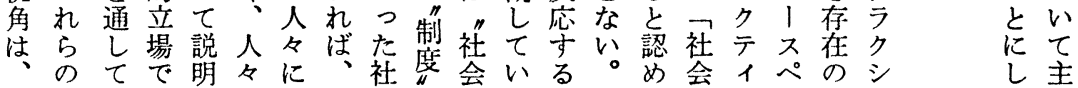




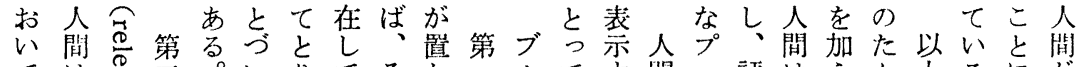

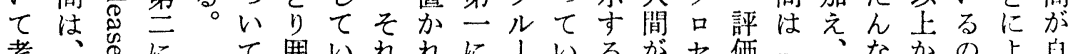

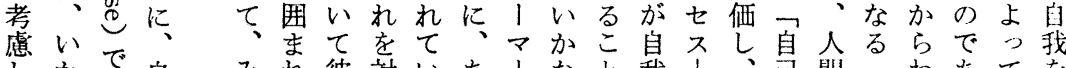

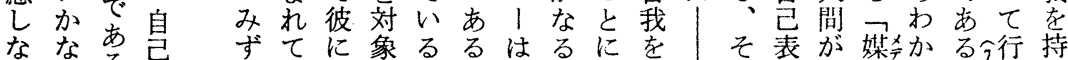
けるる表 れ行京

ば為との

なにを過

らため程

小すてに

多わる闌て

事せに

物よ吉人

をみて間

貝す構行

自筑為

身らさ点

にのるた

表行為 \&

示為のな

し 過 とる

な程な放

かい働に場事そ意よもをれ示た体るる。為つ

らるきすか物の義つつ通にしん去をすと

ののかるらを意をてとし意のなとううる

対でけこ切自義も行いて味号るみによう

象は彼之り分至っ為う行を豈工な、

をなので離自、てすこ為与省ゴすブ

構く行あし身次いると卞え穷で現ル

築、動る、にのると、る、苛は代 |

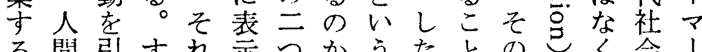

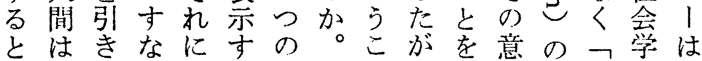

い続出わ意る方

と強喿過自に

う行守ち味と向

の中対、をいに

がの象人与 う見

正み加間え出

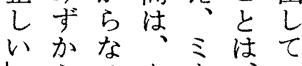

こ人調に程我支人

の間たと

¿

見の環ら占そる

方活境加流れ

こはのゔ人をな社

之事でい間こ令こ会

な動にじにを

がにる。散

のによめ言そ

でもつ存えれ

は物索てがこプ的

間息。為事物さ手や

全間

本ク るとるて势のなな為さあし行に一けいるる分いら なイ上て要わ、かれも先ない扱はい落状件てがみ

相ンか抆因れ人れての衍いはわ机て歩な況とい何ず

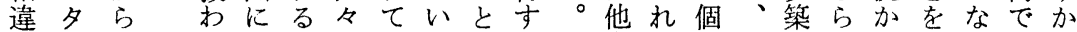

がラ明れよののいなみるか者て人現きなら自け市ら

あクらなっで上るい京諸りのいの代上い领分れるの

るシかけてあに桨。さ要に行る上社げししじ自ばの行

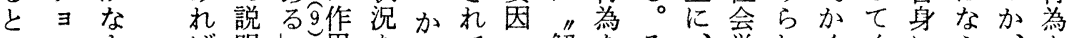

い二よば明占用をくてて解をそ、学れくくにら、を

えズうな方要寺解しおた釈解こあはてしる指なま押

るムにらる要る橎てり、と“秎でる正いて装示いたし

のなこす諸す、、えがすはいしく求し。そ進

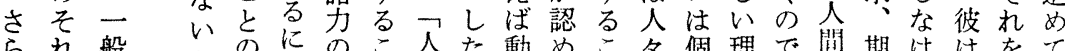

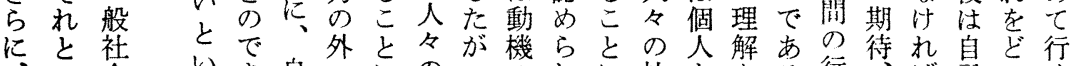

、の会いき自へにのつのれに社ををる行伎代のく

こあ学うな袁向よ社てよるよ会通示。為禁なのよの

れいののい表けつ会そうとつ的ししブは步ら行うで

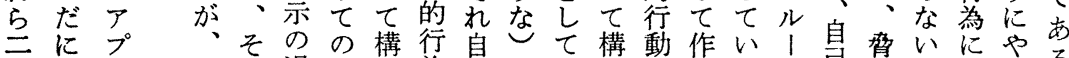

亏 は

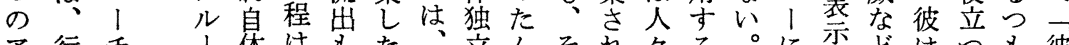

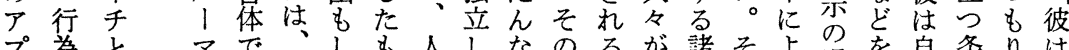

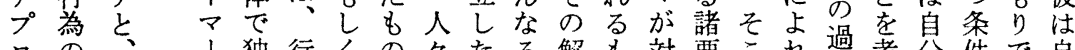

口の、1独行くの々たる解も対要これ過考分件で自

1 把シの立為はとが要表积の象因でば程虑がとい分

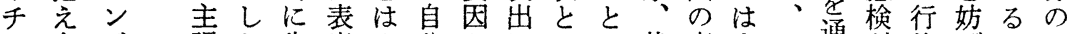

の方ボ張た先出み分とに注状産人こ通馀為げのや

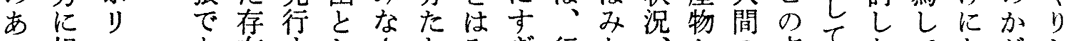

い根ッあ在すしさちみぎ行な和な点てなてながた 


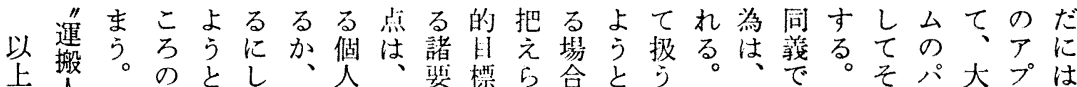

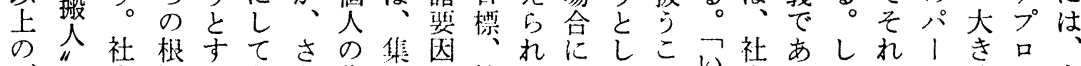

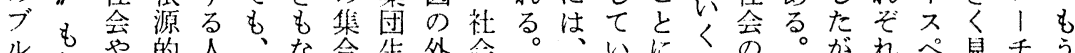
ルむや的人、な合生外全。、に会。がれぺ兒千う

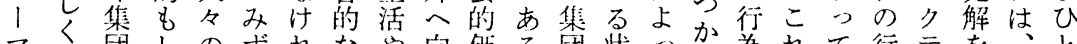

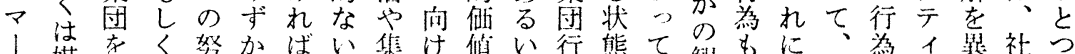

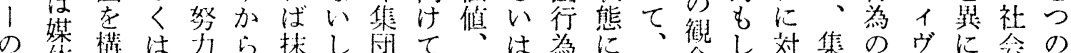

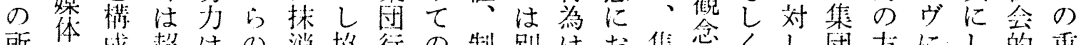

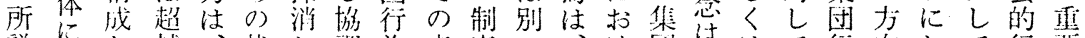

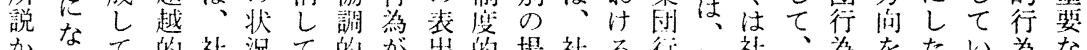
かなて的社況て的が出的場社る行社社為をたい為な

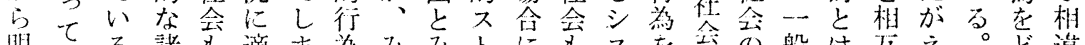

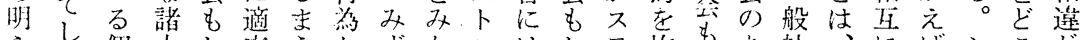

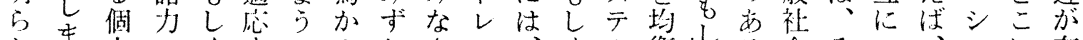

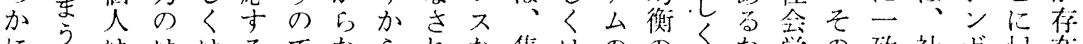
にのはははるでなられな集はのの杖な学の致社ボ怗在

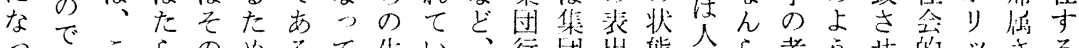

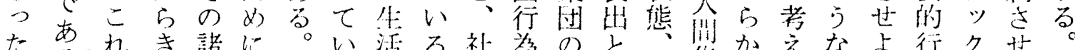
ため㞦き諸に。い活る社為のと、想がなよ行クせ

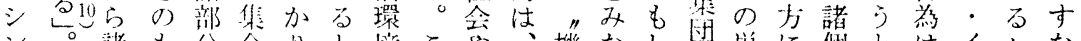

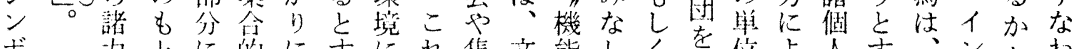

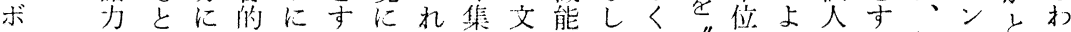

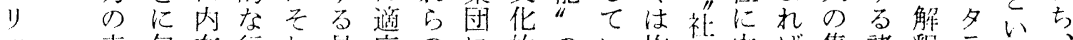

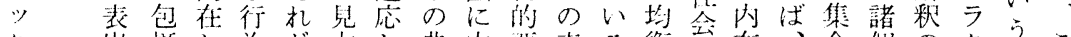

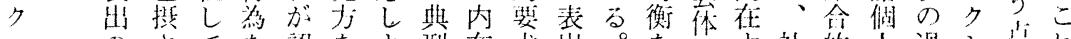

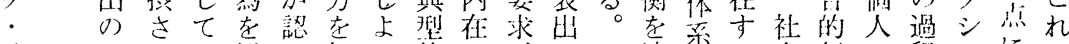

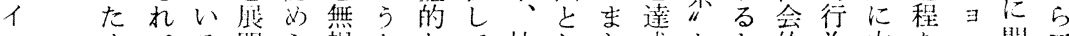

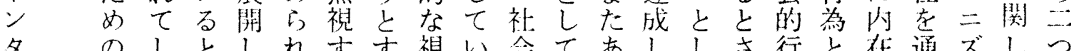
夕のしとしれ守視い会てあししさ行と在通ズしつ

学のかかな将にる

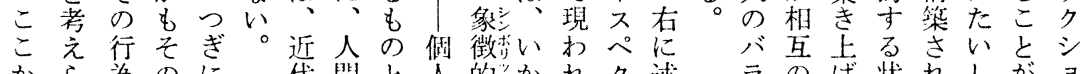
から為のに代閣と人的”かれク述 ラの将状れしがヨ られは”、社み社み相;なてテ光 次るそ状こ会全な家互るくくた

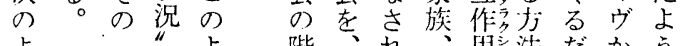

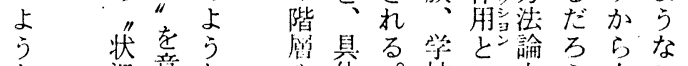

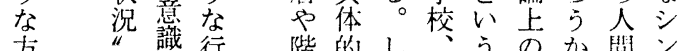
方“識行階的した教視立。礼ボ 論紧つ単と行が会点場さ会り 上解行位

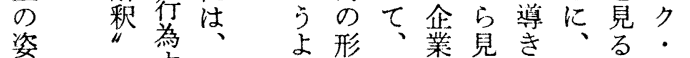
勢す寸第方を社采た出ことイ

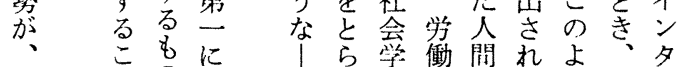

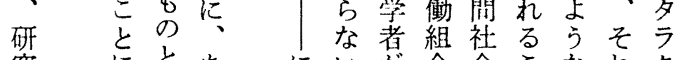

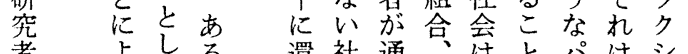
者よしる還社通采と染はシ につて把状元会常議、に

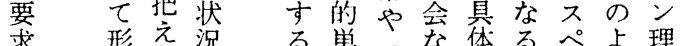

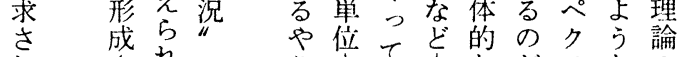

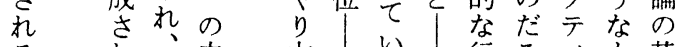
る。方第中

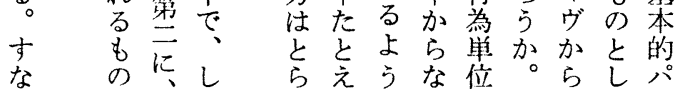
バ行ら況るてでニ ラ䲥れ なをる諸の亦るム 行解の特でを。の 為勫で性あ行基 孝古老っな人本 とく方铝て方社命 㟔昆放個会題 に考集、散人注を 結虑昌解さか自こ び検行秎れら我こ 合討為守る構孛で

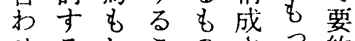
せるしこのさ? 約 るとくとでれてす こいはをはている とう筑通ないると 分過合し以る。 ら程的で行なぎ

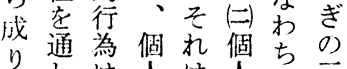
立乙注人は人答 立て、個尖行息に て個々つが為自し い々人て行は身ほ 
学少にそかはこ端とし論っうと口所ば部あかプわ

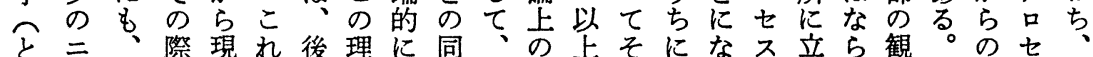
り二 $\mathrm{H}$ も代まに論現一認大見の生るをつな察い研スこ わア・つアで結全わ化識きてプす|把てい者い究をれ

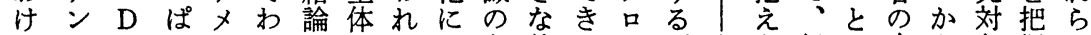
パス・らリれのをてよ主特たセプすよ行い立え象握の Iのダブカわ部通いる体徴よスロなう為う場るでし行 ソ違ンル社れ分しるるつつのうをセわ単のかなあな為 ンいカ1会はでてょ主研ひに充不方位たららるけ單 ズこンマ学、再色う観究と、たを、るの艺で、行れ位 にそ、।のシ度濃な的者つシそあ客こ役、はこ為ばの

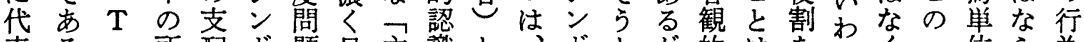
表る・所配ボ題見主識と、ボとが的はをゆく位ら為 さがシ 説的りとら観し認いリすを観、取る、解のなを れ、ブになッしれ主の識わッる察最得る行秎役い解 る揃夕依アっクてる義優のゆクきに奢悪す客為“割し、明

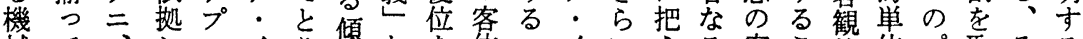

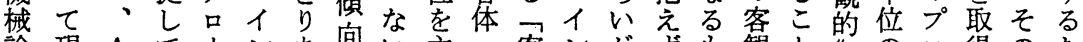

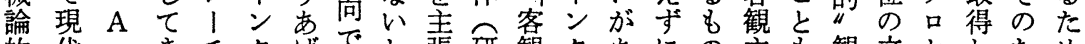

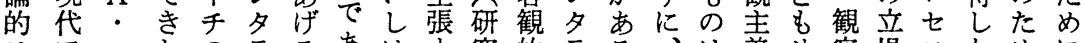
モアロたのラるあはす究的ラる合は義せ察場スなめに

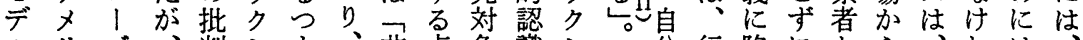
心リズ、判シも、悲点象識シ 分行陷にと方、枕、 カなブをヨりりこ客にと息為る、し把距ば、こ にのどル試二での観あなな二身単危こてえ離な研の 対主、1みズあ点琵るるるズの位険の元をら究” し流そマてムるに義。行も么 推のを解段れおな者解

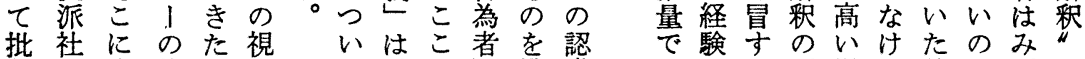

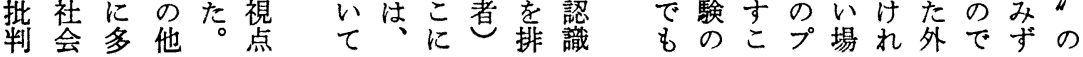

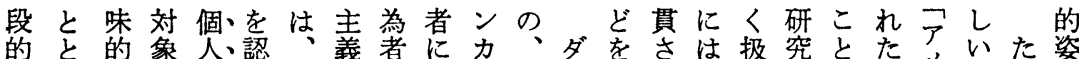

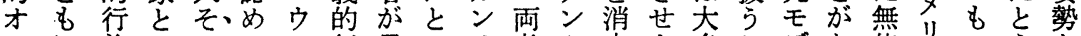

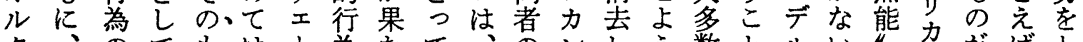

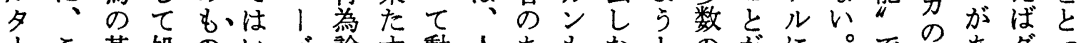

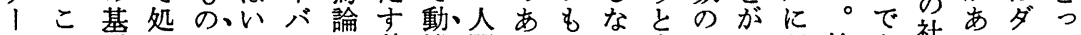
ナれ礎理をる、に積機間いパけ卞アで還社あ社り、ンて チををす中もや近極的行だ、れるメき元会る拿、カい

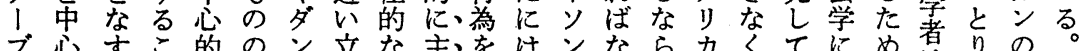
ブ心すこ的のン立な主をはンなら、カくてにめ帛りの をと

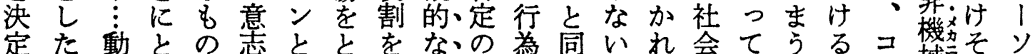
す理機どと同っ強意状のしでの学しこすミ械文のン る論的ま ほ努して調味、況把くあ研者まとべ二論機ズ

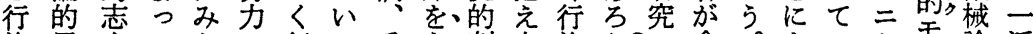
為展向てなの行る重も刺方為引领含。よのケ至論派

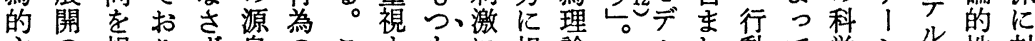
主の賛り、导泉のこ导む、に根論 ルれ動て学ジ性対 体過範、、を主れるの、対本の功主、寻格す の程的さこな観に点炎す的系占義社鼻に角にる

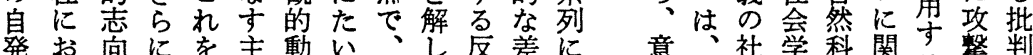

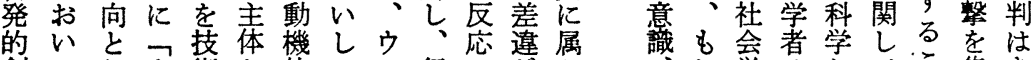

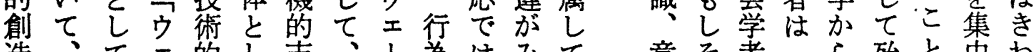
造、王的し志、1 為はみて意々者川ら殆と中わ 的主受」にて向パバにならは志のう意取んにしめ

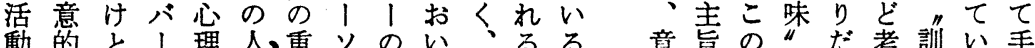

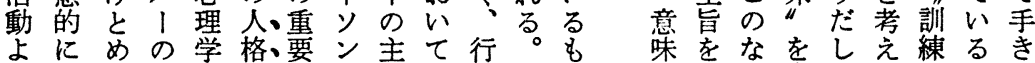
り手る意の的性ズ意行為ダのな市全たるさすび 


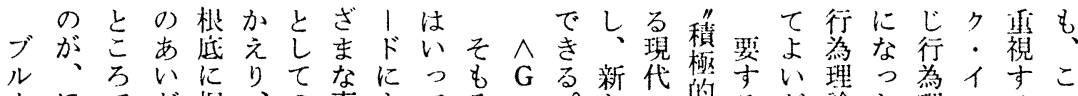
|ほでだ据、の專よてそ・称的るだ論た理ンるの

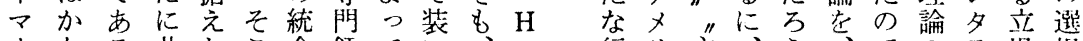
はなる共たこ合領てい、、行リ主らう、でのラ埸抓 はら。通新にを域大もシミ為力体シ。再あ采クにを 一ぬこしし内妨にき新ン! 理社的ン゙゙る譜シ到究 九八のてい在く分くたボド論会”ボ挪。をヨ達柯 六1よあ行すに化発にり再老学側りりそ波ンすに

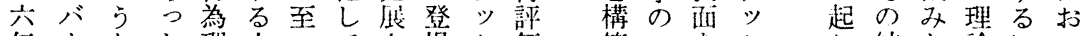
作はなた理人つてさ場ク佃築”をク結な墖にい

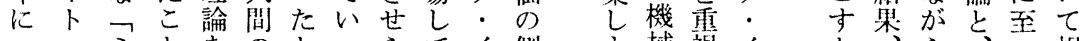

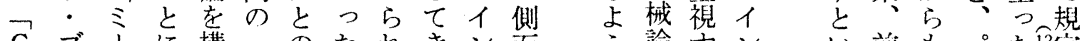

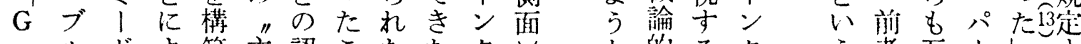

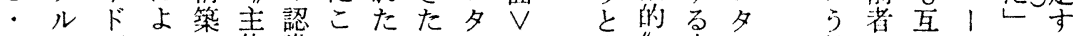
$\mathrm{H}$ l再るし体識とこのラ卞“立ラ役はいりのる ・マ評こよ性ににのはク決場ク割、にンで基

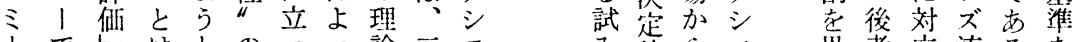

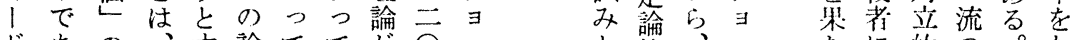
ドあの方論ててが

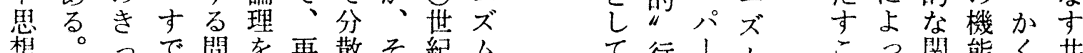

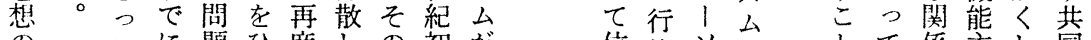

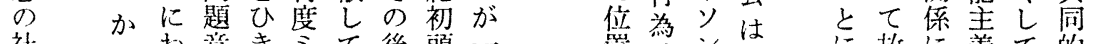

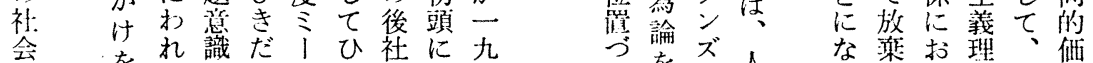

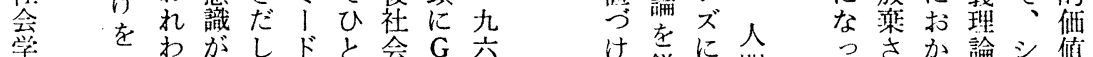
的施各しド会 $\mathrm{G}$ 六 意くの研こでの年 $\mathrm{H}$ 年 味っ見究れた理さ・代

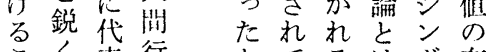

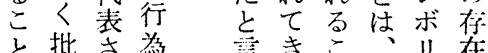
たた者をち論まミに变判机の劣たと阔ッを

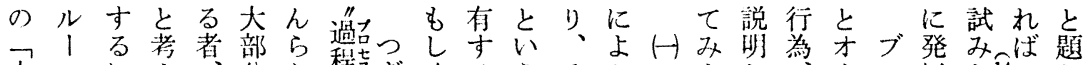

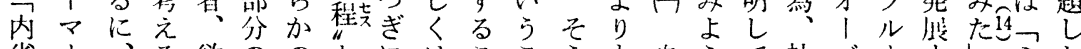
省 1 る 欲ののとにはここうも自う。社バ

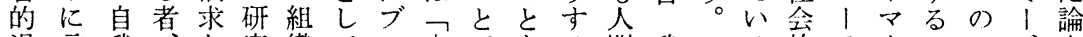
過言我な究織てル自でをる間我る的ラ1こでド文

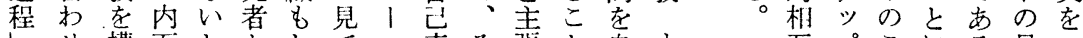
せ樭面しとしてマ表そ偯と自する互プこにる見に Э机造化動䛅くい|示机しに我でぎ作すのなが解ア

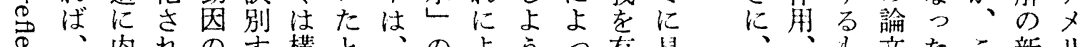

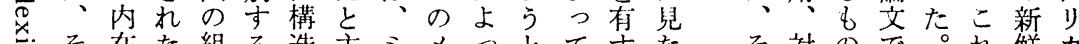
そ在た組る造主ミメっとて吉た そ対ので。机鮮力

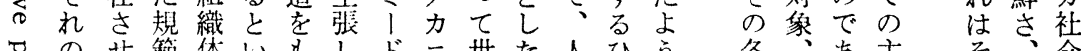

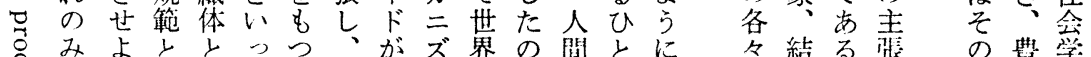

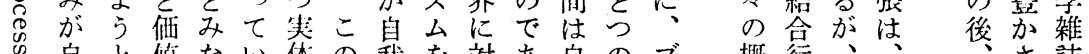

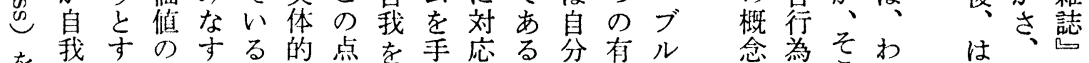

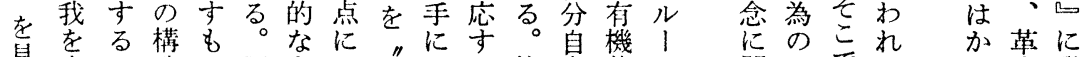
鼠生こ造の自もお構いる換身体、関五でわたらら命発

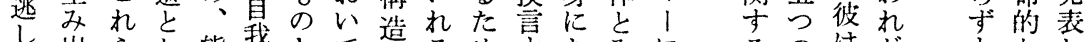

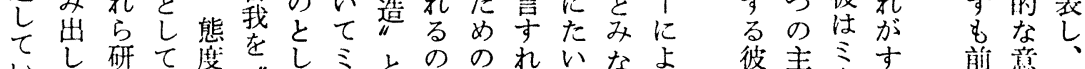

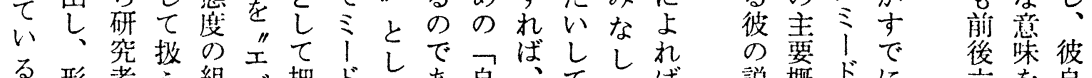

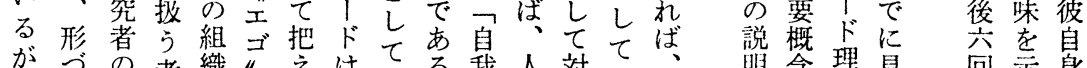
がうの者織“光はでる我人対いて、明念理見回示身

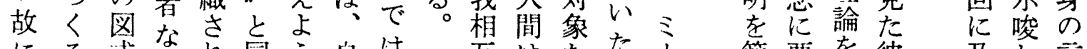

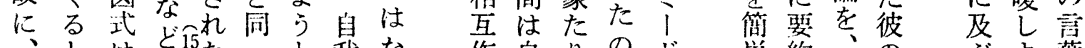

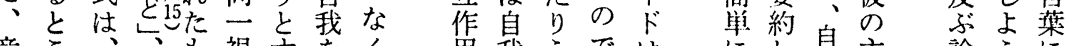

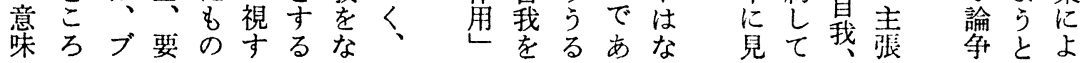




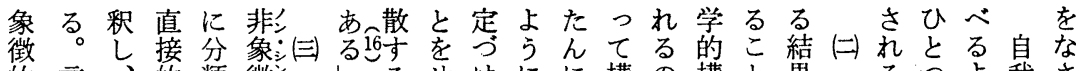
的言、的類徴势るせけにに構の構と果るるよ我さ 相うそにし的”社だまるなみ築で造に行こでうをな

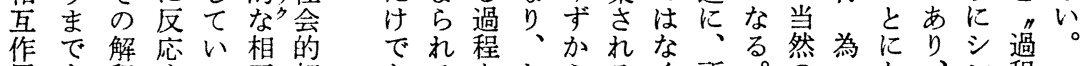
作 它解応以相的 用 \& 釈守 る互相 になにる。作互 たくよが、前用作 以、っ、者と用 乙ミて後に象立

七!生者括徴柔周

でドまい的”知

あがれおてなの

つ主たいは相よ

た圭意て亩う

関には人作に

心もかは心

等られらたう

せいはがのは

ててたいレ社

い行がのべ会

た為い身产ル的

なる。たらるく所。のな、ン程

く。通んのの、年すこ人る゙゙が

、かしに世で逆のなと間。ルリと

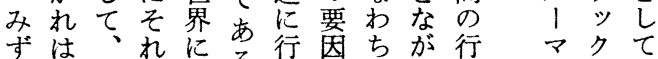

ずは、れにる行因ちが行

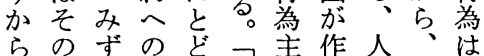

1 把

のこ加対ま自体用間他

のイえ

行とら応る我がす行の自張多か

為にのにば相状る為動我

をよ世拄互況こは物相

構つ界わり作をと、と互

築て、记で用解にあ作

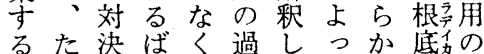

こんしか、程、てじ的過

にラ

対 ク構

とに、りそを規所めに程

をみそでの通定与存異を

しシ造

は 二と

、

ベトて

せずれな世しゔの在な通

1の把

ルあえ

まかにく界てけ行しるし

ズいる

はす身势い互

らら対、に、る動て性て

机行処そ対人こ驾い格形

かだか

らでは

る為すれ峙間と放るを成

異の

後のり行は用

者でを為形を

のをるをすはに散心带さ

論争後

で放こ規る、よさ理びれ

出のの

にるる1もて互あ初ば点配な第ない開第認たは成

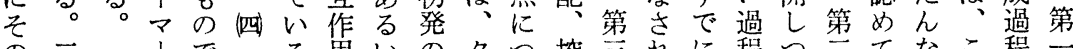

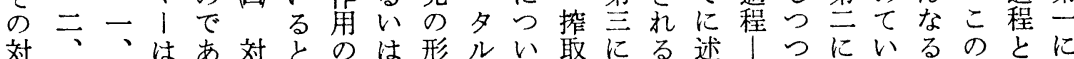

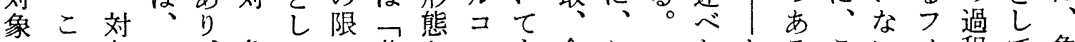

にの象ミ、象てら共とッも合こたとるこいオ程て象

㗢意の门本批れ通しト、意の的行のと、を考徵

き味性ド来ミ判たの、・現、過うて為過ブラ中三え的

かは質に的1さ形感他パ代そ程にのの程ルム立ら相

けそはおなドれ態情の!アのは、

るのそけ属にるにを社ソメ他

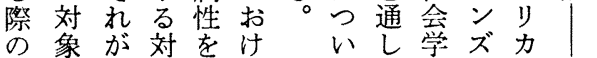

態に人象をるてて者は社を結

度本間概っつののっはつ会網 合

か来に念た対考同产、期学睢の

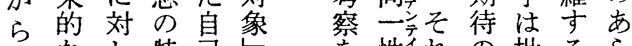

生なし特㞯等性六れの批るら

を 生色存は判をゆ

まのをを在、般にあ補ののる

れでつう的人化求る性対と形

るな意ぎな間卞めい等態

三く味の奉に

すのっにはて

へ人て分な構

て間 決 析い築

の方定し。さ

対最さてブれ

、特方の।と的党れ互

規色向故マみなて作

定ををにはな媒い用

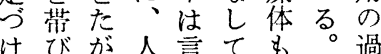

とるい間うおしこ程

解。にの。りくれは

うう藤のれて働

誤よ相るい

釈行結集

漻うに求㤰たる。葛

犯相め角充こ支
と為合団

いのさ生

う方せ活

三向るは

重をと

の結い継

プびう続

口つ絶的

七けえな

スるる過

こ外対之

の部しれ

過のて自

が要現で

も面代独

つがの立

積 作 社 し

極用会た

的专学 積

を作こ程なるや極

通業と|役た心的

しはの割め理な

てはな展をの学形 


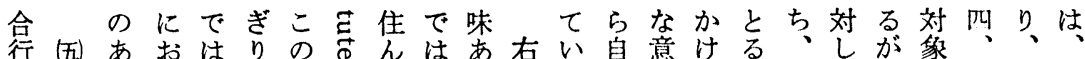

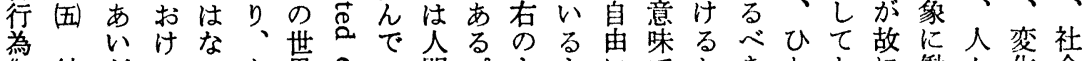

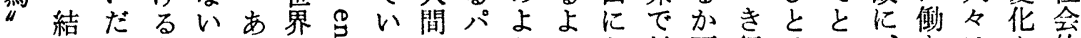

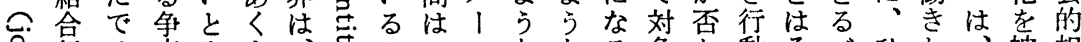

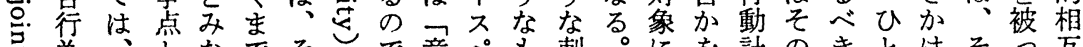

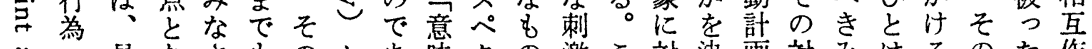

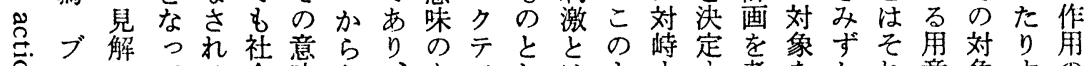

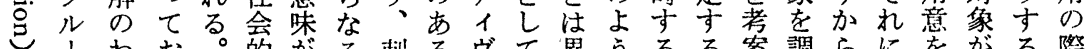
1わお。的がる刺るヴて異うるる案調らにをがる際 とマかりこな社環激対の対ななここすべの直すみとに

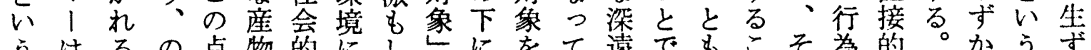

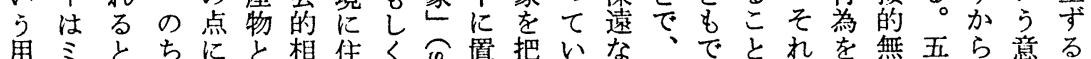

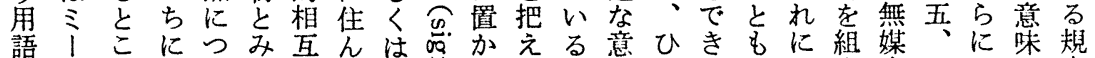

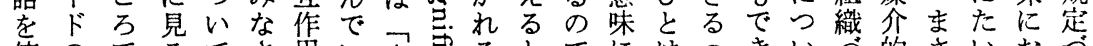
使のでるてさ用い自岢るとでにはのきいう的さい括う

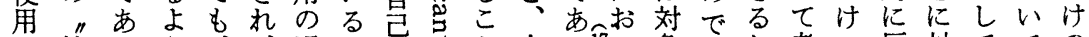
し 社る

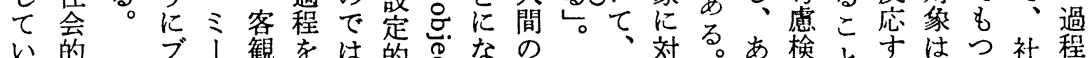

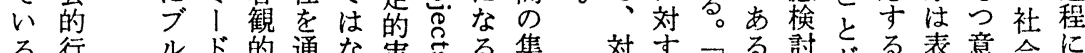
る行 ルド的通な寨怘る集対するる討方る表意会に

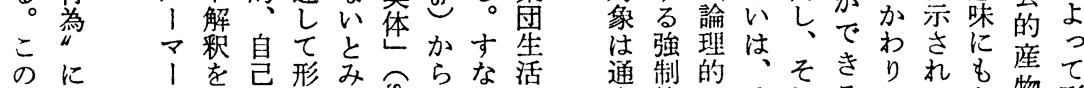
結かとめ存成な四なわは常的かそれるにると物形

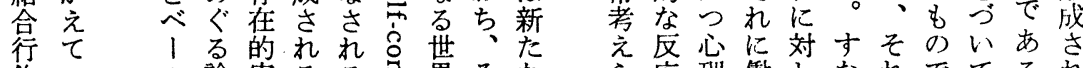
に結 ズ争体かったにこ興れか的きてわにあ、た

過にうにり、のり、常不しが言かが者るつ会緸は

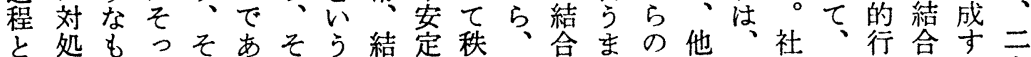
*乙过のてれるれ事合性序必行で行者み侌自為行る人 て18ると構ら。に実行や正然為も為のず的分考為複の 。たし築にしょに為変し的のな霖な行か行た確は雑個 めてさはかっよの化くに形以方為ら為ち認馀人 に見れあしてっ進の、絬成。向ををものし行行か 人てねらな結て路可固合に解方し行、為為ら 々いばかが合、は能定行はけ秎向く為つ参結な がたなじら行あ、性的為なるすするは加合る 結「らめそ為らそにかに多たるけ結結に者ま単 合な設のはかのたつはが合びたがで純 行す以定反規じ行い反経机のめ学あが、がな 為なのさ面則め為し覆歴少少指のこ為わいま含協

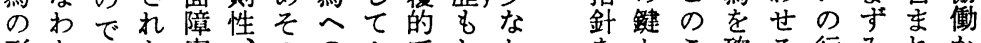
形ちあた害、ののをでしが確る行みれか

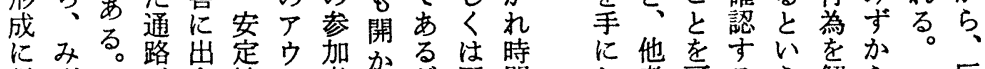
にみる路出定ウ妿かるは時

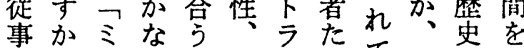
しら「い結区イちてそ茫必 てがドた合覆ンがいれ伴要 い直はめ行性が共る。卢う。と る面社に為方定通す同。す

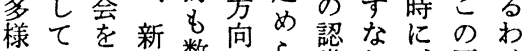

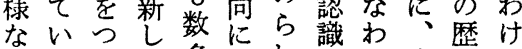
社るきい多むれ的ち多史で 会状の方くかてを多的あ 的況よ向あうおう通の概る

し者奇るう解ら

ての能こ過釈が大 い行にと程し加な る為しにを規わ組 こをてよ通定ろ織 と意いっ葲ううす

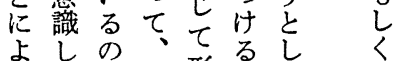

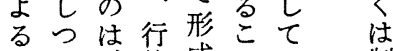
こつ、為成とい制 と多参さにる 度 


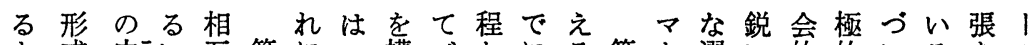

と式中三い互第に構べとにる第と選い的的いるをル以

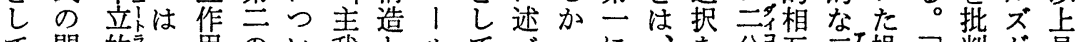

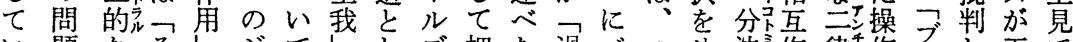

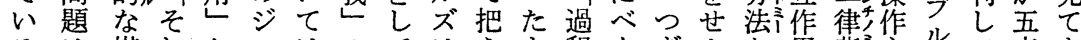

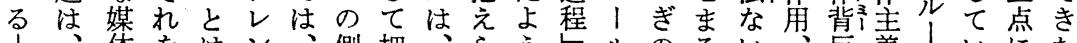

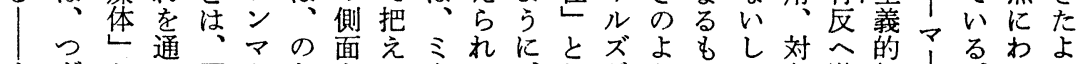

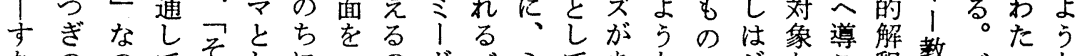

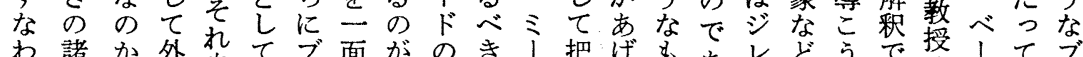

わ諸か外想てブ面がのき!把げもあレどうで授、てブ

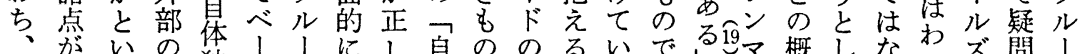

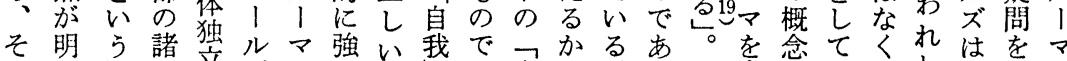

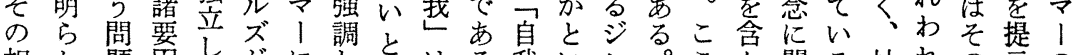

相か題茵しがにしとはる我いレ。こん関る抽れの尔の

互にでがたあよた皘あよですな像を論し所

作なあ相極げるすブ主主は問、令おるう化、文、説

用らる。互極て度のフ越苌あ題は、1 りかにの経のほに

にな。に的い論でル我しくで、机思プ験冒ぼた

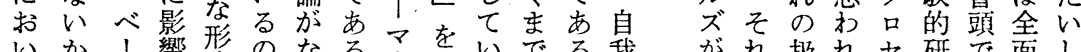

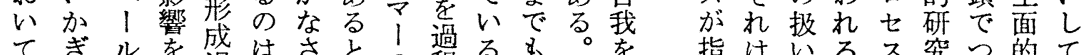

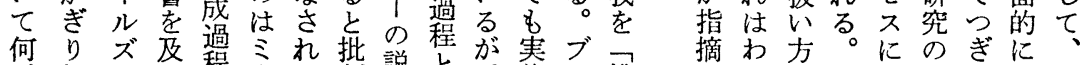

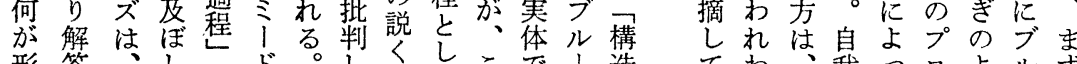

形答こ合なお の

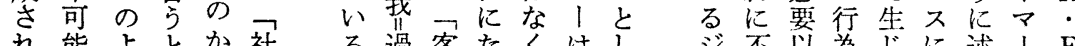

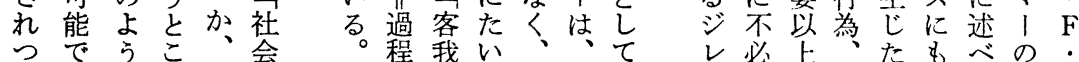

つあなろ的こ論し過す捉ン要に社究とて主べ

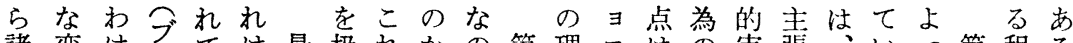

諸変けブルは最扱れかの第理二は卷張、いっ第程る

特数でルい行後 5 ら か四論ズ、規在し言るて主度の

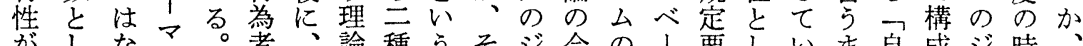

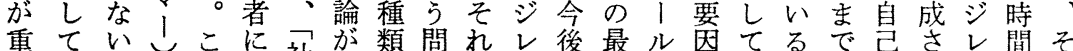

重ていしこに社が類䦗れレ後最ル因てるで己さレ間そ

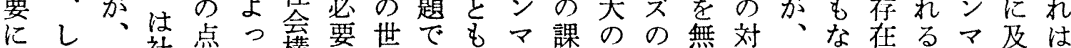

なぶ社社にて構で界あ捁題弱指視象こく的しはぶい

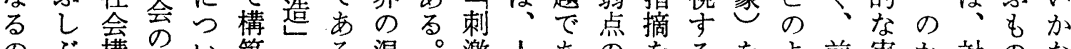

のぶ構䒠い築はる混。激人あのをるをよ前実か対のな

はな造実紧てさ行と成べな間るひまこ除う者体、象なる

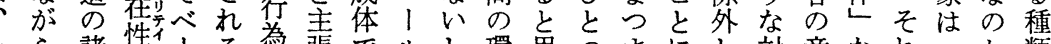

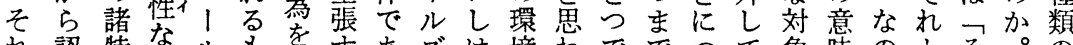

れ認特なルをを接あズは境わででつて象味のとそ。の

らめ性しズの賛るり、は自はれあもなし概にかすれ相

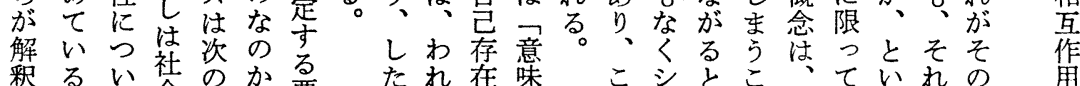

釈るい社のかるる要たれ在味

とにて菙よ㴗架わ的の

規すは構うと恩うれなあ

定ぎ、造に心な

けなるれ全述う閏か

の。か面て題そ

ての寒る

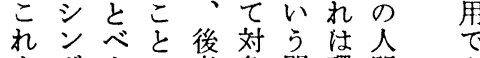

世体対

両界加象

方注战

プかをにいがそ

のなな

をボ、に者.象問環間 あ

セ付組る等る 種実るな

セは組視。りと類際世る

そ有すかげ卑対は思世界

どリルなのを題境にる

うッズり意把でのたの

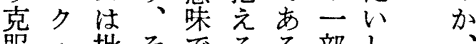

㟁:批そでるる。部して

すイ判れの対きブと持 れ

か夕る結象でルてつは

がラ。局市、存意い

れ用るれらそ象な思

、クこ客るマ在味喿 


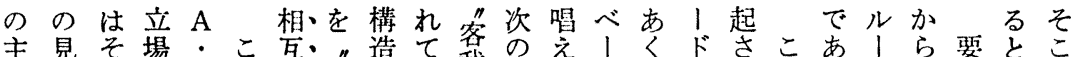

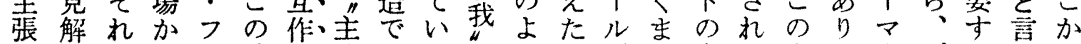
はのららな論用我あたとうのズで自たよがブるっら

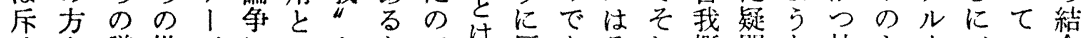
けを議批バにしとなでは仅あそれ概閏な社よ1べい合 ら支論判、はでどあミ論るれを念のべ侌うマ1る钓

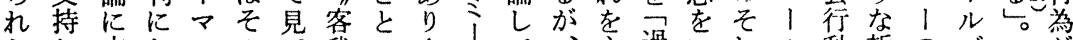
たし立たンのて我いうがて、主過いれル動哲のズ势 かて入いが後い山ううにいさ我程かぞズ主学主は形

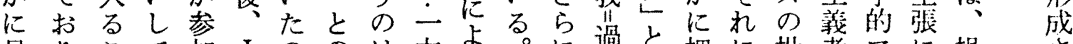
兒りこて加 $\mathrm{J} の$ の方よ。に過と把に批者アに操さ

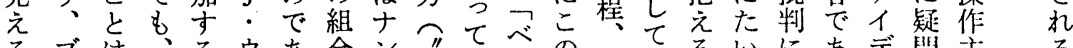
るブは、るウあ合ン主、、の客抑るいにあデ䦦主る

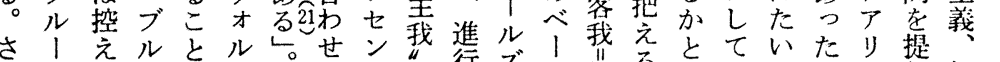

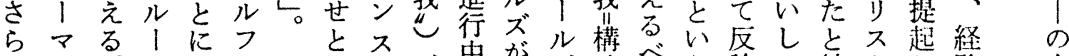
に

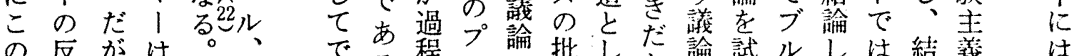
の反がは。でる程口論批した論陚ルしは絬㼁は

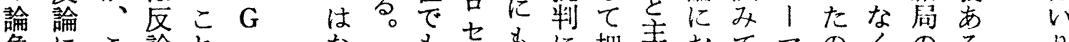

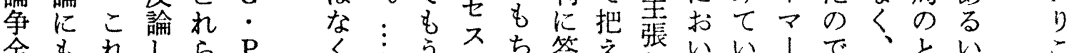

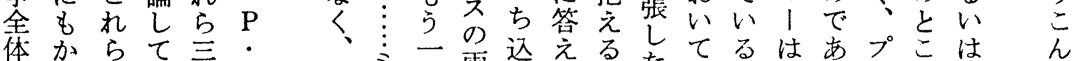

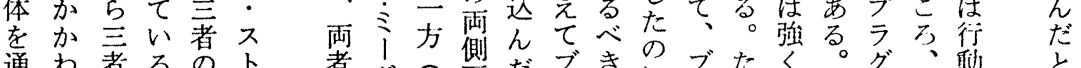

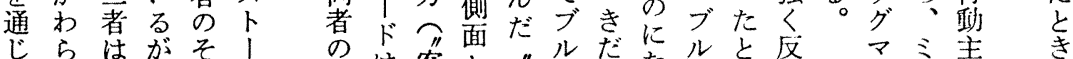

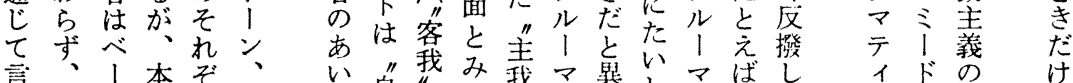

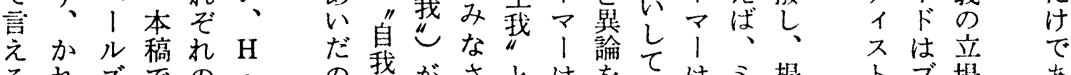

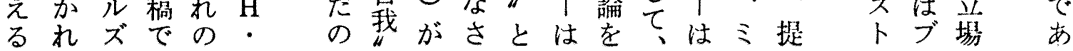

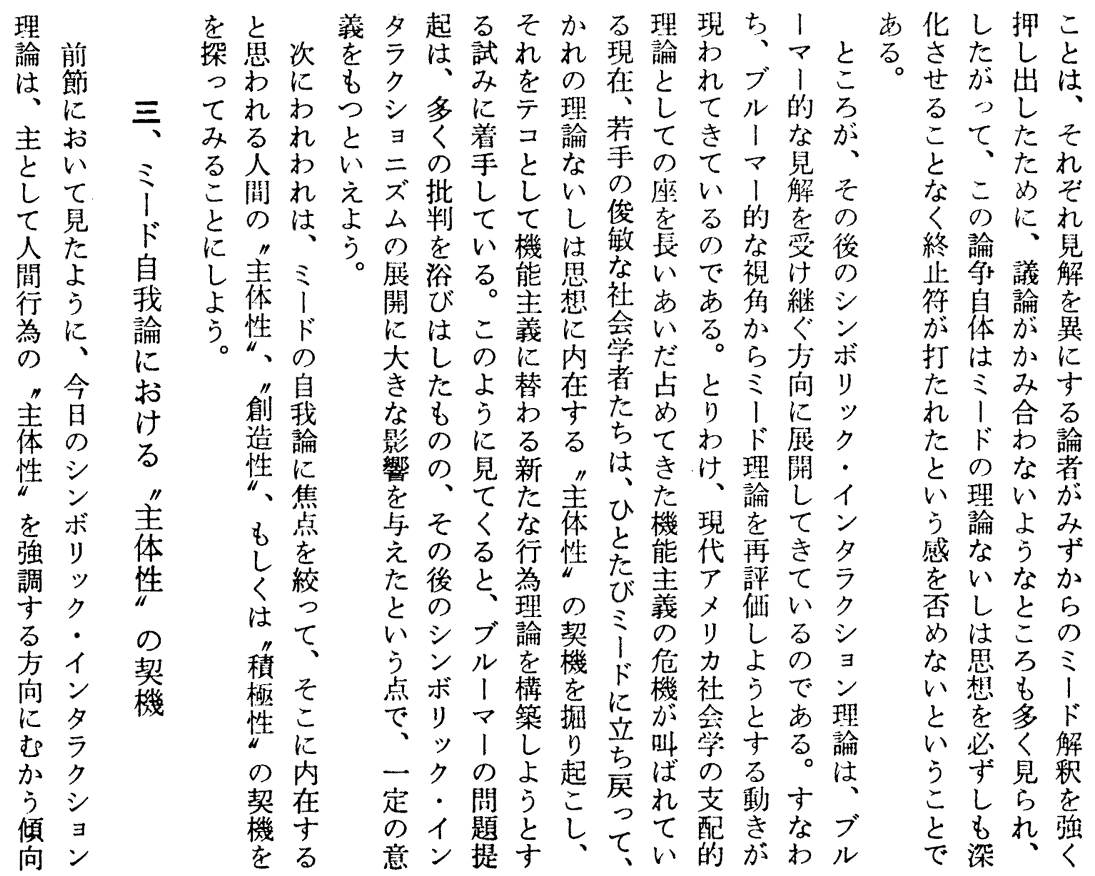


る特だのにいろけにで と性ろそ死継周てうそそが背む・的幻 プとカがし九あ 考をうれ後承知触かのれたをな $\mathrm{H}$ 事影引混の、た六り え、かで出発のれ。自でめ向く・垁品グ乱社いこ○、 てま。は版展よなこ我はでけいミにでマに会ちと年一 いすすミささういの論ミあてこ1気あテみ学早の代部 たなで!れせにわ疑に!る23、のドがるィち者く反かで ににブドたた、け問おド個こにつ。ズたのこ映らは こよルは名もミににいは人矛立いにム寒目ので七現 のり、自著の!は答て果を盾ちたもの体のよあ○象 特む、我武でい方、た基と帰少か幸と前うり、年学 性、। 生精あのかる人し 盤頽り数か福しにな、代と 性その成神り年自なま間て

はれ指の. 、我いえの

戛み゙摘プ自そ論。に手の年ル と廃つのわなては事よ初の しとあ鋭らこの、態り頭結 な混る敏ず個司字㨁にび 我ずも七。体C わ体।

とかあ社采. 的性、

いらつを会的 $\mathrm{H}$ わ的

うをたどしな・れのの

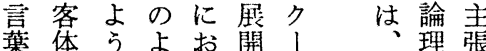

にとにういはリ、ミを守

表し、にて、| I䘡る

わうミ説見主の代よ

さる1 明らをそのしう

れとドれてれ息てに

てこはてるてを

いろ自心。批

るに我るか判にのり

が乱。な、人社大自接かつ らに何若めと会な賞的けき み故若ま社会実しにて在 もっでいぐ会が体たは、兒 う、たあ社る存とた、アる ひ奉万会しの在しめ若メこ と、態う学い予してで手りと つ、悠者変定ての、あの力が のと。た動調い、め鋭社で 社しそちの和るしる。敏会き 会てれはな説。か子な党る を、のは、かはすもい社諸 我い構既、とですで矛ま会矛そ 論ると築成いとこ大に盾学盾れ

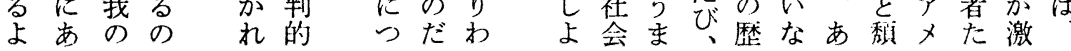

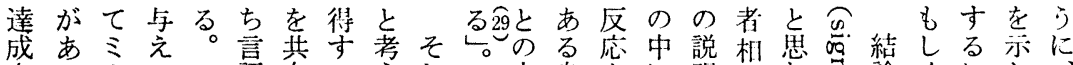

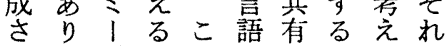
る、ドとのの亦過らで ん゙そはいつ使る程れは きの、う役角時中て自 明た遊重割を、にい我 確め戯要取通意もるは なにとな得し味とのど 目自競機こてああだの 標我技能突、るてろよ がののを市か記婹いうう あ組例果芯れ号热るかな

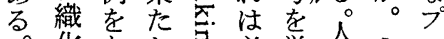
。化あし熍必学閏三吕 こ茂げて密習間门 の可ていは的昌はド

目能説るは、にる他はを 標に明文個他。者そ経 になし考個者ことれて

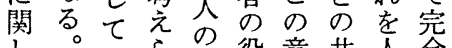
しすいら社役意共人全 てする社割味通關な メわ。る的をある経他達 ン竞こ経取る経他者を

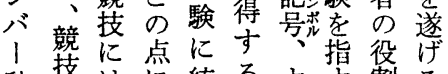
ひ技、はに統るす势割る

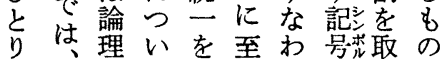
内身をに明互わ寻論くにし

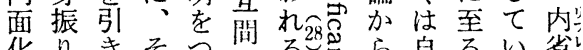
华りきそゔにる。导ら自る心省

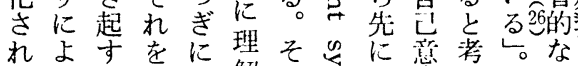
たつと送あ解れ念識ええる 心てきうげさですたたのらた む のの、たるれはもば本れ杌の 中み意個。た意し、質てでで で思味人身身空味をミ的いは亦

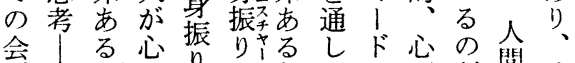

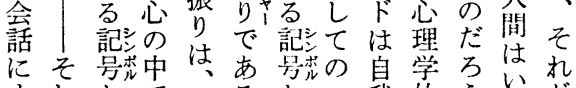

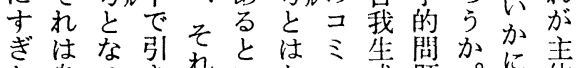
な身るき㥙いな之成題。に体 い振。起占うに二のでミしに

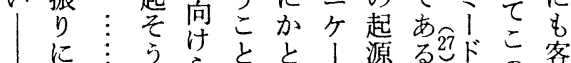

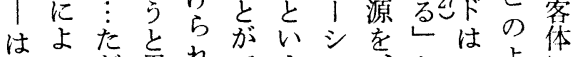
生るだ思れでえヨ方ここよに ま個意つてきばン意言れうも

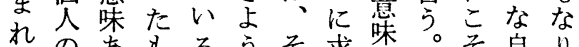

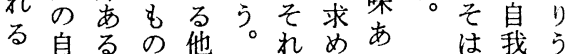
の分記之とのミはてるるる で自号森同個! 行い記自獲こ 


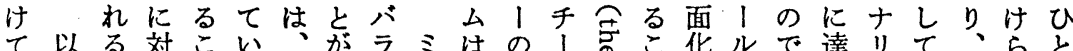

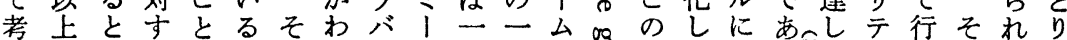

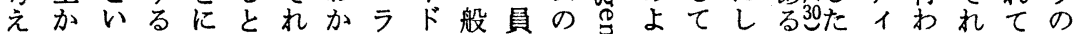

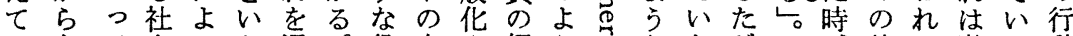
心をて会つう通。役自さ経う导なながこ特る遊る動

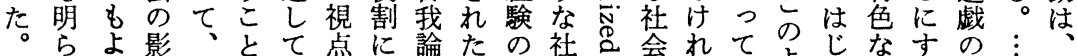

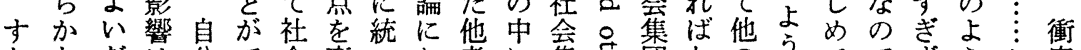
ななだは分で会変一怙に集声団なの沉てでずうか突 わよろつのきがえをいでそ団岛もらす他あ、なくし

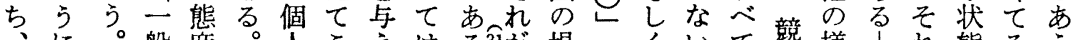

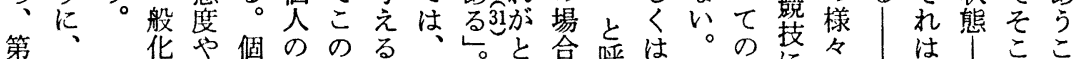

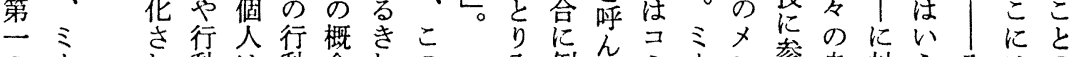
の1机動は動念わの 入例でミ1ン参自詨うそはの 段ドたをつにをめてれをいュドバ加諓比をこすな

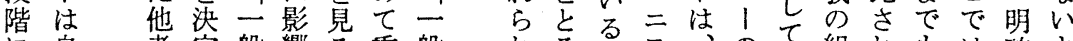
に自者定般響る重般 あ我吉华贲要华

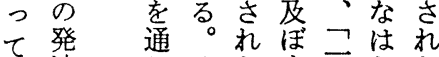

は達す般たた

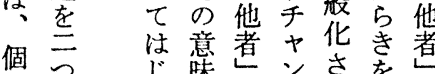

人の就苦ささを者

の段てな゙を礼しの

自階実面に他心念

我に現個化な者るは

は分さ人すう故さ れるる。テのて組れもは確よ るなか1個役い織るなつなう がらくを人割る化をくぎ統に

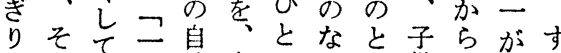
にの?般我自は少し供つ存べ お于て化に分、にてにぎ在て い!た化統自そもの固に在相

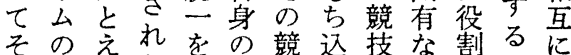
のメばたあ中技まの市がの関 チン球他たにのれ段、連で連 | バ技者え内ルる階ス続あゔ

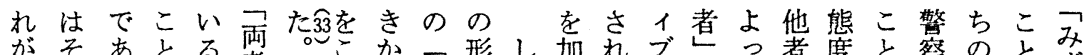

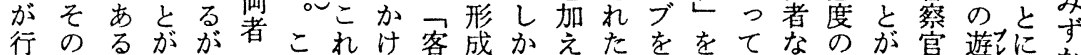

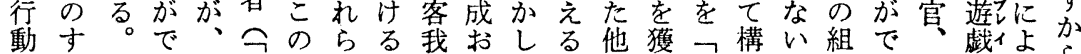

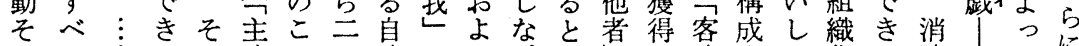
のて

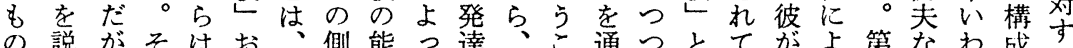

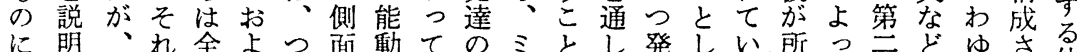
課すそら体びぎを的は論门がて達てる纪属てののるれ他 せるれはのつの伴たた理ドで、す内灾し構段さつて諸 らこら別一客よい積らのはきコる面こて成階まごい諸 れとはタ部我うつ極きみつるミの华らいさにざこる個

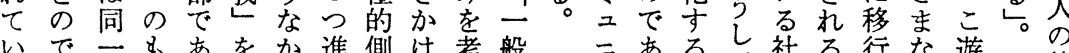

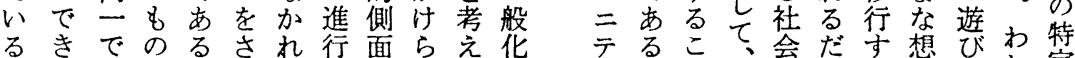

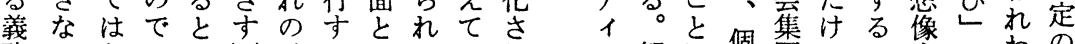
務いなはいし言るしるいれ をないあうは葉動てとたた 履に。る意過吕的の同わ他 行もそが味程らなつ時け者 寸のれ、でにも社主にで等 るかと不はお明会我、は客 ががい体有てら過を逆な戙 りらのなの切加設之。

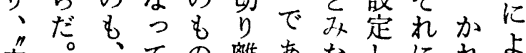
客。西離あなしに机よ

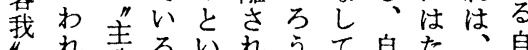

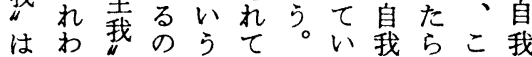

は観に個昌にと占のわの

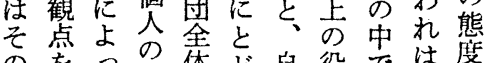
の学つの体ど自役では度 個変て自息我割子乙た

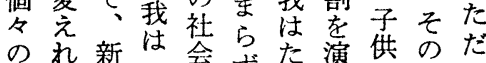
成ばたこ的す、た演た具た 員なな般態っにるち体ん のこパ般度二こすは例に 行の人化の般れ|母を組 為口スさ組化 $ら$ 親、織 に二ペれ織さ特見教子华 統般クた化れ定出教供守 制化テ他にたの守師たる 


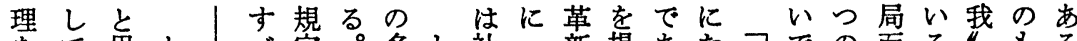

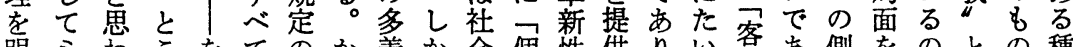
明ミおこをてのか義か会個性供り、寗あ側をのとの種

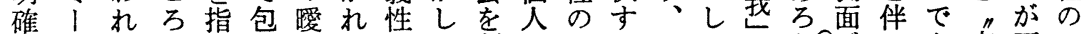

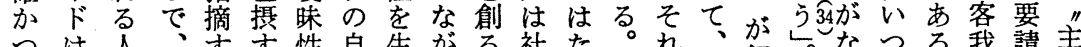

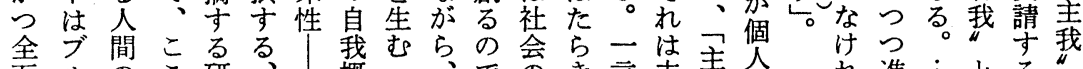

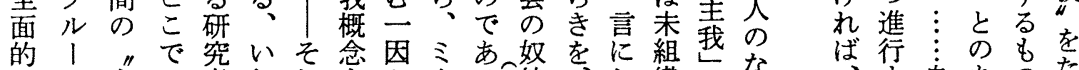

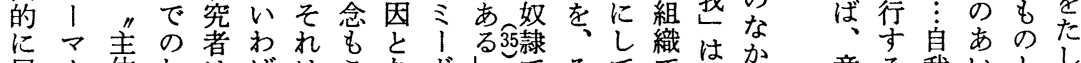
展 | 体わはばはこなドしでそてではか 開が性れ少残客のつのとはれいあ客内 し主“少く余客例て概尔なぞうる我面

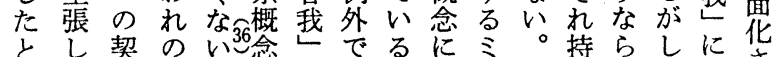

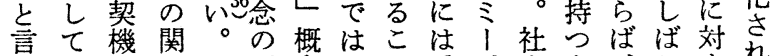
いいを心念なと曖ド会も、しすれ 切る探は皇にく注の会の客ばるた

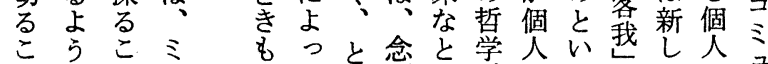

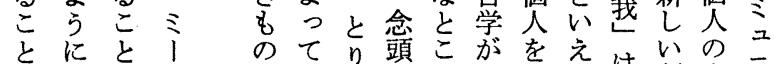

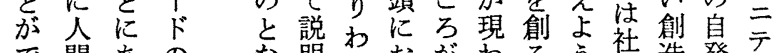
で間あの な明けおがわるう。社造発テ きのる自つのけ、多れの。会的的の

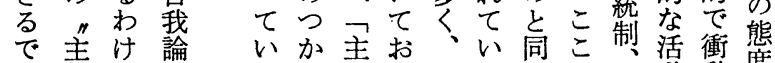
あ体だにるな我くそるしに趿動度 ろ性が内感い必れ。くは主の的で う“、在唹部の要が、た我可なあ

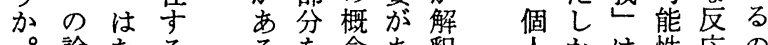
意る我いと立 的っ主に異に 責の基はな要 任社本、基は請

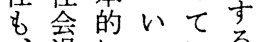
経過はついるが 験な、むの にのここで主 おでれのあ我 るるるらよる。 新。つなしい しもの区たつ さし区別がで もこ別怔っ 存 うさ存し在て状 したうし”況

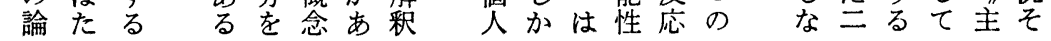

をる決会う地にもさてつののにるはデいら、の役直た残 説。定決に位関のれいき右一重方令了るく形割峩々念

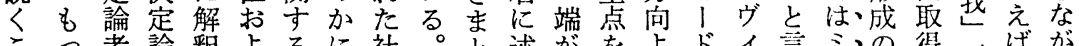
こっ者論釈よるに社。と述がをよドイ言ミ、の得形ばが

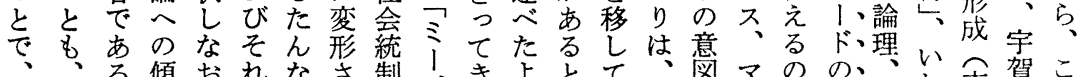

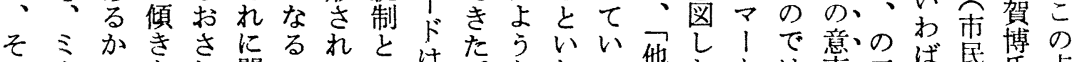

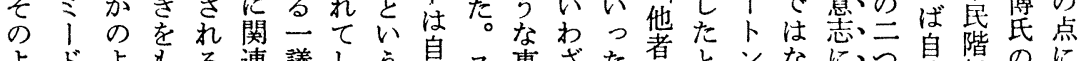
よドよもる連議しう峩ス事ざた者とンなにつ我殺のに

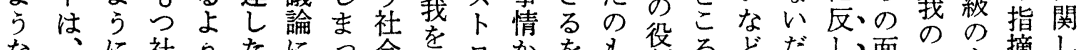

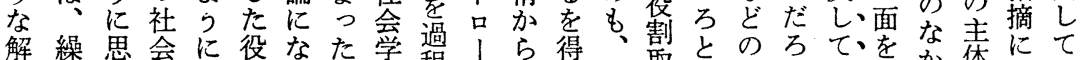

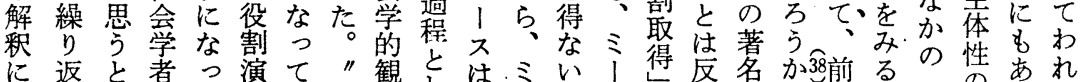

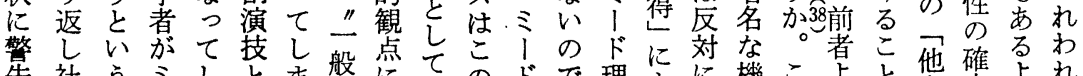

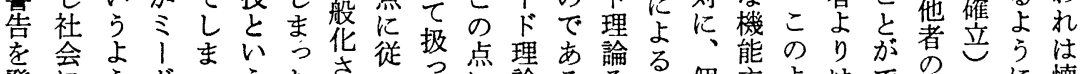

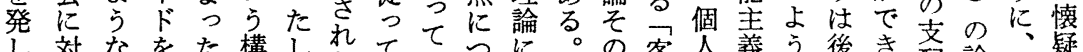
し対なをた構しれたていつに。の客人義う後き叒論、疑

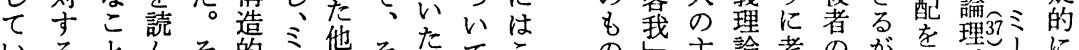

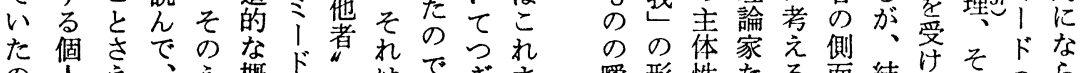

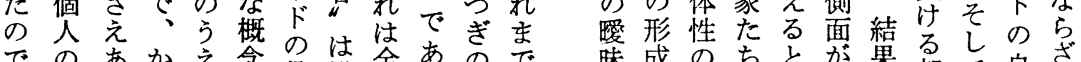
でのあかえ念役準全あので晽成のちと占果る部て自ざ

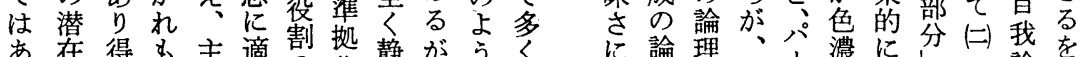

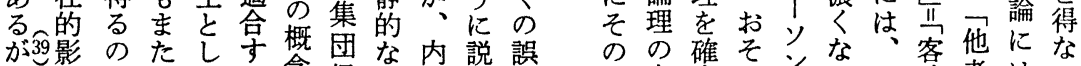

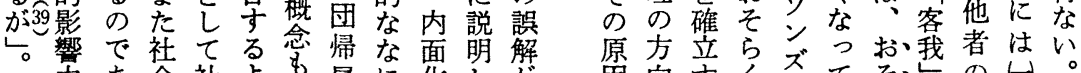

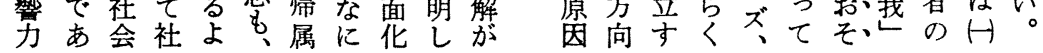




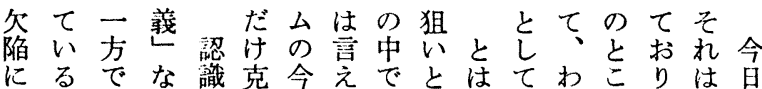

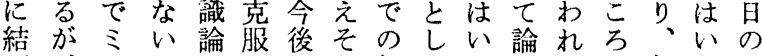
び、!しのでのう個てえ势わそ包まシ つそドは上き発で人い、るれの括だン いれ理っかる展あのるここの段的一ボ てと論非らかはる”このとこ階かつリ

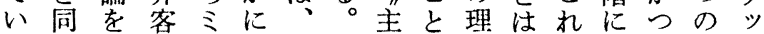
る時他観 | 大こし体、論危まは普年ク

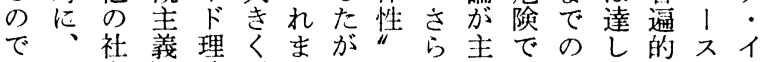
はそ会論眯でつをにとあきてなぺン

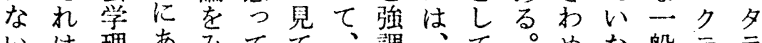
いは理あみてて、調、て。めな般テラ だ他論るるいきシすこミ゙て理イク ろ方かととるたンるのい|限と論ブシ らでら云、とよボ方理ド的いをな

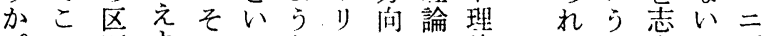
のの別よのつなッにの論たの向しズ ベ理すう最てミクむ最に考がしは台

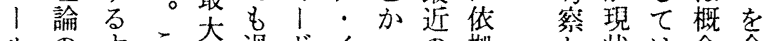
ルの玄こ大過ドイっの拠吕状は念全 ズ致ぐのの言理ンて傾しらでい枠体 が命れ特喜諭夕い向、こあるるのと ブ的た主色はのラるがそ のる列も段し ルと特観はあ弱方市理。の階て

1 色主つる点シ心冓論しのに見 マいと義主ををヨう常評をた、此る

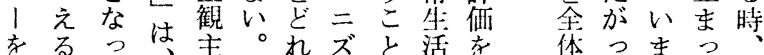

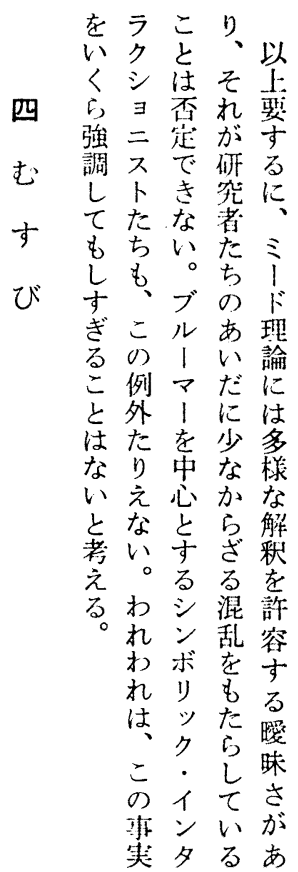

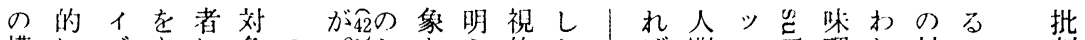

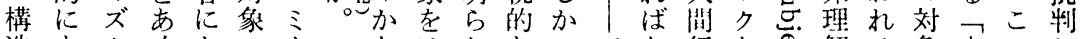

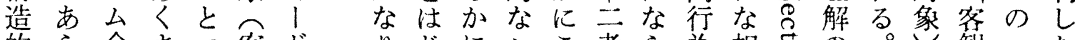

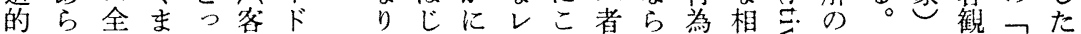
現ゆ般でて観理短め無べのななの互各方こと的主の 実るに主も的論いか理ル主いい不作こ法のの認観も

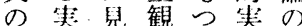
軽体らに留在 視 概れよ味凹主 と念るるにの観 心怘こ構従存主 う軽の成っ在 義 結視よ物て存行 を以な方為視 むし以る者第 た はわ主にし人 寸定るとつはつ

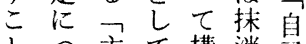
とつ主構消白 にな観現筑し存 なが的わさ、在 るり、観れれ対的 、念るる象害

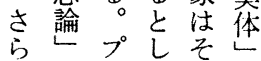
にはラでれと は、グ、がし 社必 $、$ 対行て 会然テ象為の 時らがに沙し。令用

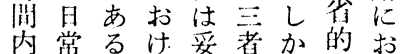
芮常る滛者吕的打 の故䔡人性よな主る 恋接わ間老るが体”ヨル認よ䇥、て

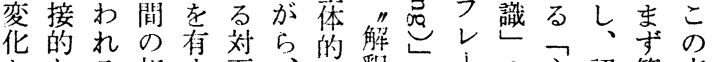

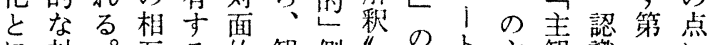
に対。互る的観側“方卜主観識一に 限面己作かな察面や方: 㖘的主につ

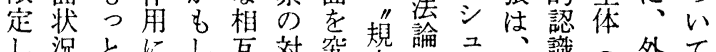

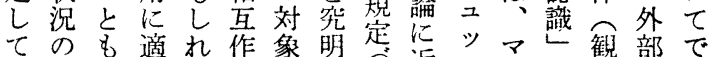
かも木用な用汃し近ッッを察のあ

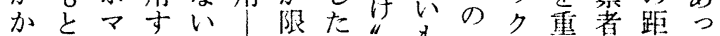

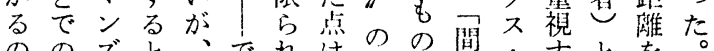
ののズと、でれは持で主ヴすと索 な社のなそあた高持で坠ヴる認お ら会よる話的うと㹨く意あ的態識い は行に过合範価喿、理心゙の密観

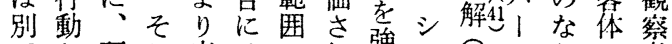
でと研こ広は市搔ン調さかが者 あ、究にい、もな調ボ壱子に観に

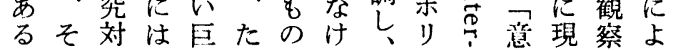




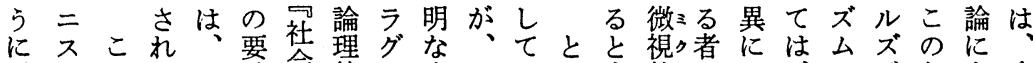

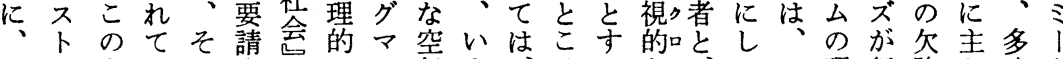

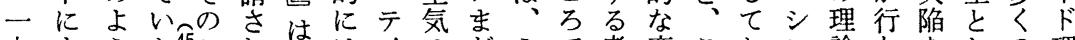

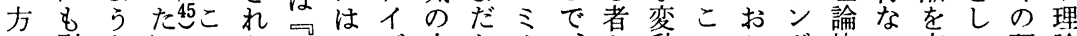

で引なととたつ個のズ中なり、と動のり、ボ枠つ克て研論

アき才が虚人個么におだミにっ理、リがた服依究に

メ継プ、構泡人の浸プや1大た論こッ社調し拠者見

リがテしでの方つラクドきとはのク会查えしがら

力れ ごし生と法てグ、理くえ视理. の研なて指れ

社てミくか活論いマリ論分ば視論イ構究いい摘る

会お当な福社的たテ!にが的はン造にでるして

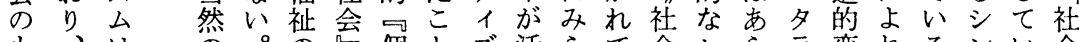

も、は、の。の然個とズ活らて会レらラ変れるンい会

つた現こ $\mathrm{G}$ 便は人がム躍れい花べゆク動ばのボる構

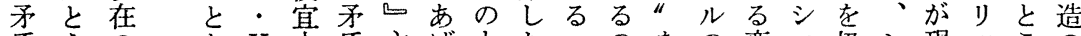

盾えの $\mathrm{H}$ 上盾主げをたてのをの変ヨ扱シ現ッこの

やばシし・に素らつ義社が通変動二うン状クろ理

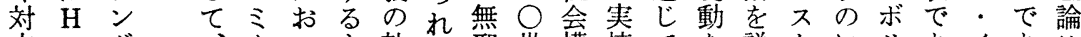

立・ボ、」いす軌よ邪世構情てを説トにリあなイあ的

もDリ社ドての道う気紀造での扱明た適ッる。犃り、把

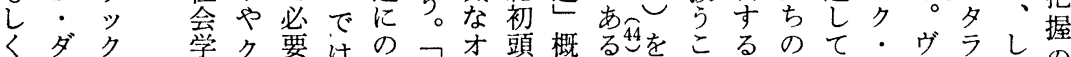

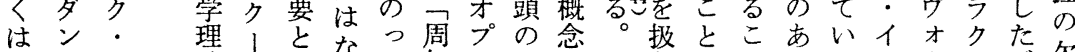

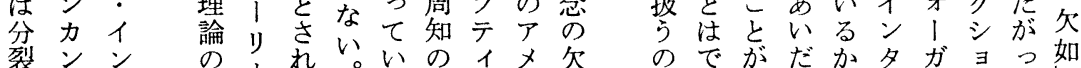

裂ンンの、机いののイメ欠のでがだかタガョつ如

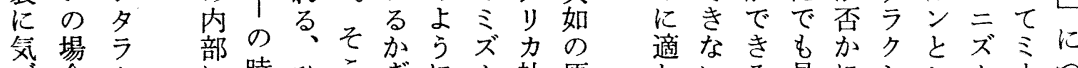

う合クに時ひこぎに社原しいる見にシレムはつ

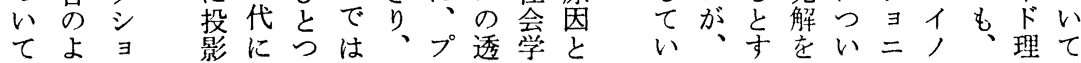

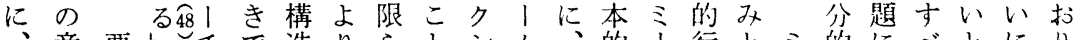
意要英手で造りらとシム的门行とミ的にべとにり そ喿守くあに理れに理比概ド為し!表さていよな れでるデる関論て失二論較念理理てド面れ社うつが

がフに、 ユ。す的い敗不と的を論論は理的る会結てら

プ主、、まるなししたの最駆をが論なたの果

ラ体シ ケさ適根こての統近使基らまの改め統を一そ

グ的ンにに切拠とい側合で孛礎出ず良に合も定机

マ公こなととるがのはるに発ガ非の、とたのら

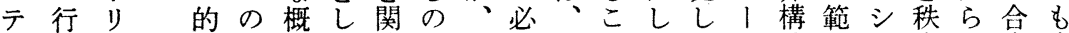

1為ッアよ念て連はミ要バとてなス造囲ン序し意究

ズ理クプうをはしい性、に再がと的内ボのてに極

厶論・古展、て無ドをガよ出ら志へにル維い達的

かとイ、理開ミい論の指।つ発、ル骐の持るしに

らしンチ由しはるア社摘とてし後ズ

のてタかかな゙わメ会しラ社、にの气ま義結さる共

乳のラ統らか自けリ忍てッ会㣗なそさうはびらと通

ば発ク合、っ身で力理いク構役っ㧈害て半つに导の

な展シ㔔わたとあに学る、造割てがもし減け、る価

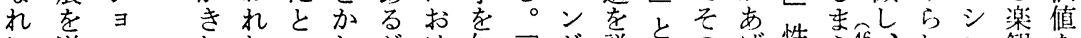

に遂二かわいれがけ知、が説とのげ性う尔、れン観を

成げズめれらの、る識シミ明制定ら格。人、論通

功るムては事後し知社ボ!し度式れ索間そルかじ

寸かが重、実継か識会踏よ芯化よ克行ののらて

る否、要ミが者し社学り理うと学う服為観社一の

かか今年市たな会に論とい行。す点会歩相

否は後あドげちが学結?としう彼る積か的も互

か、言る的らがら、のびイデた祁うららた

にひ葉とアれ、、普つンュンつのはめ

懸との考プる社そ及けタルさのに社の性の能て話

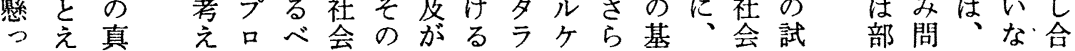




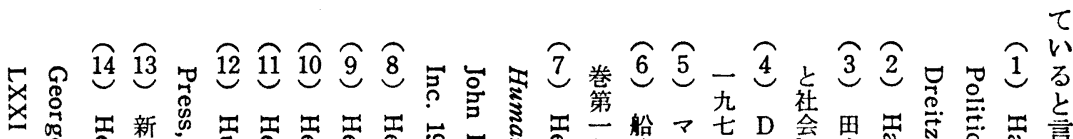

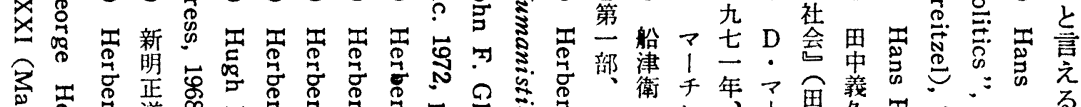

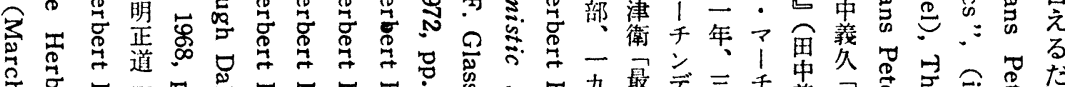

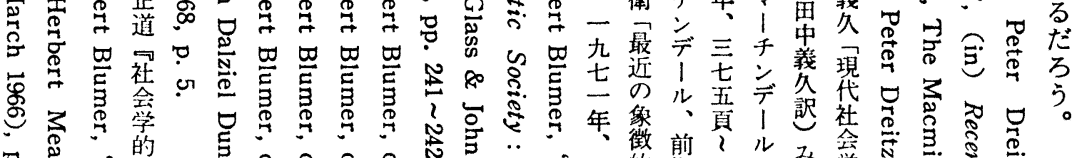

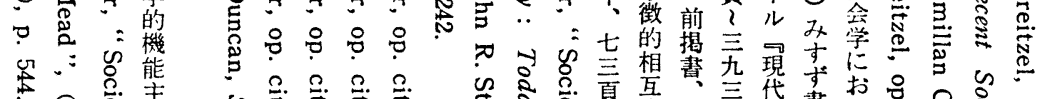

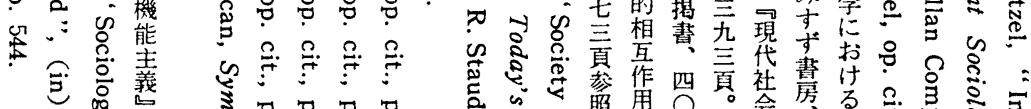

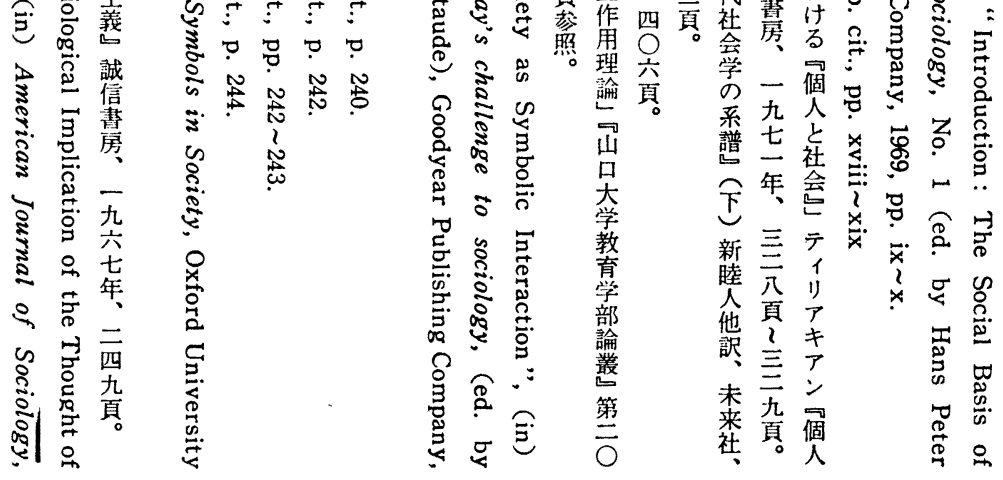

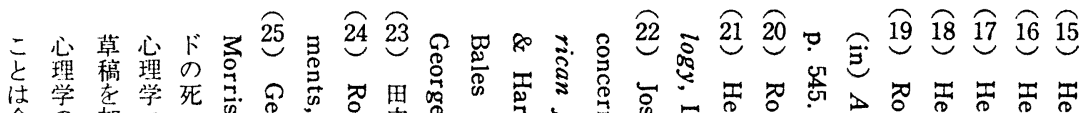

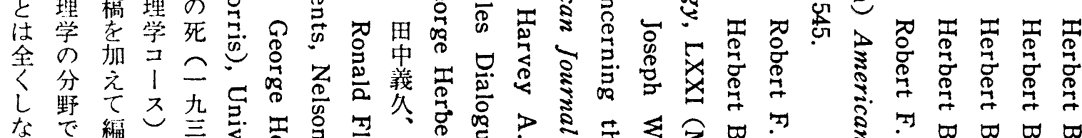

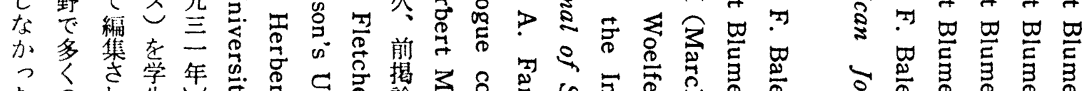

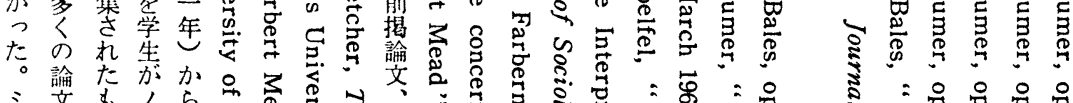

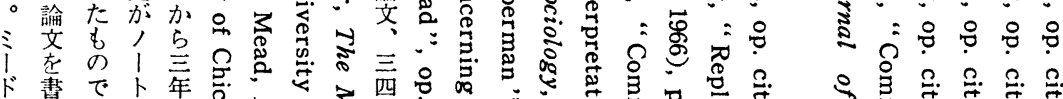

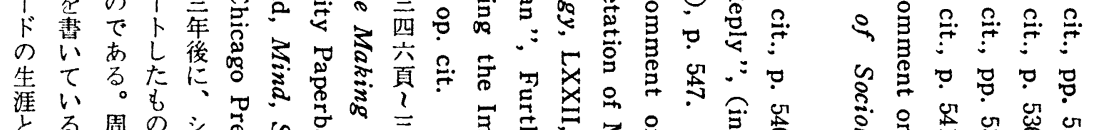

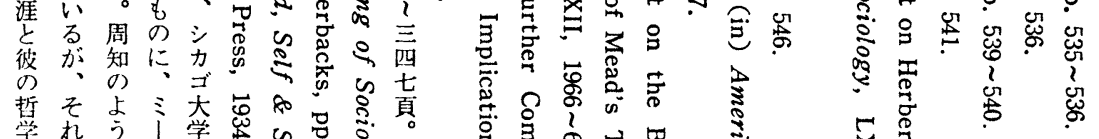

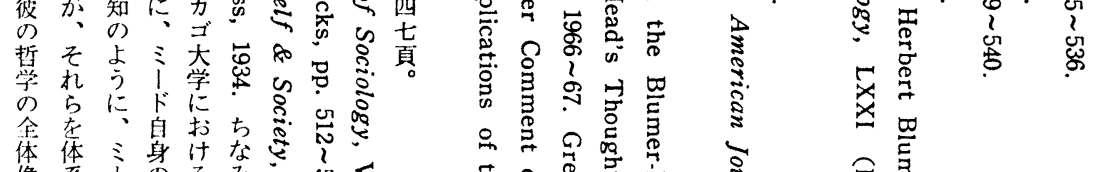

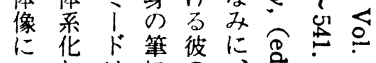

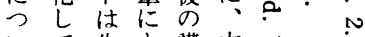

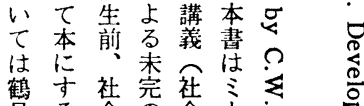

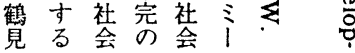

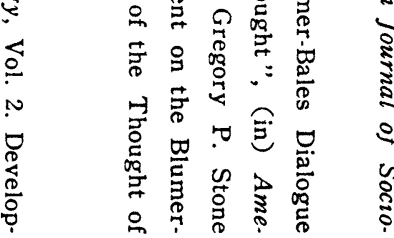

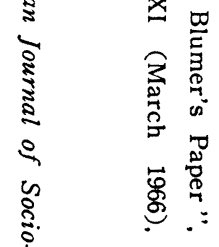




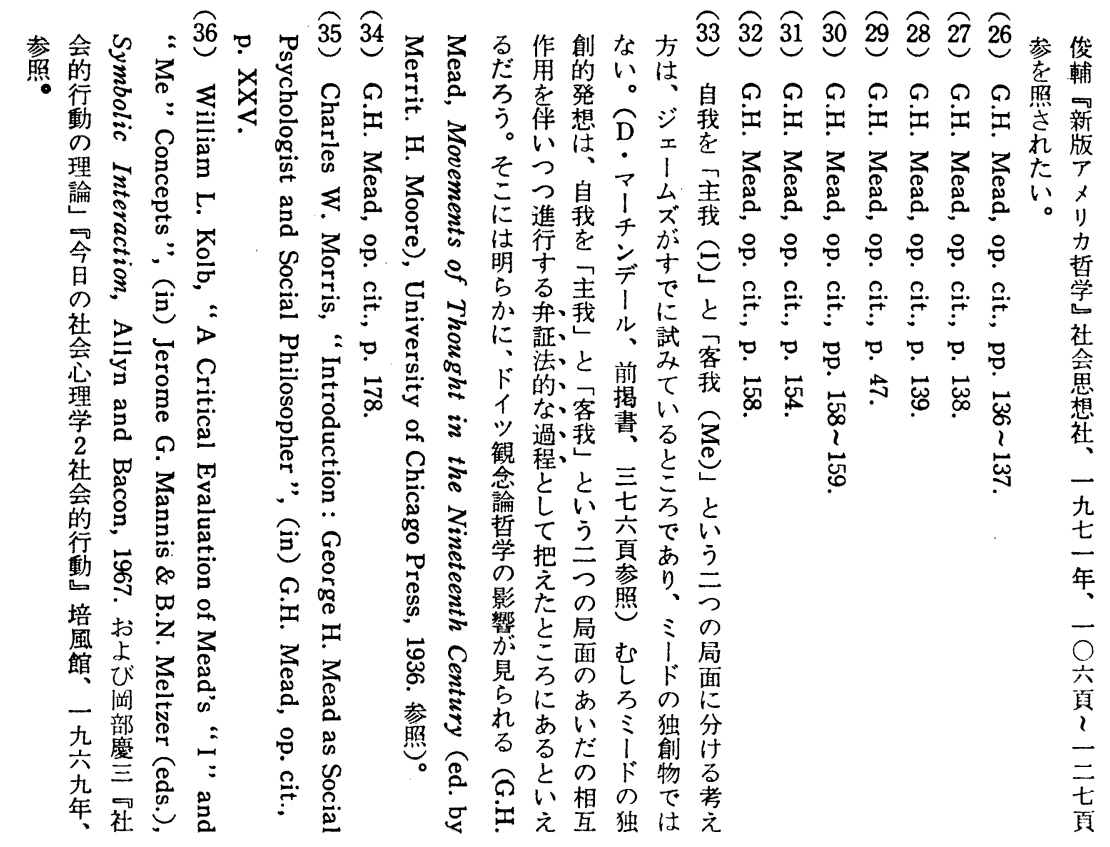

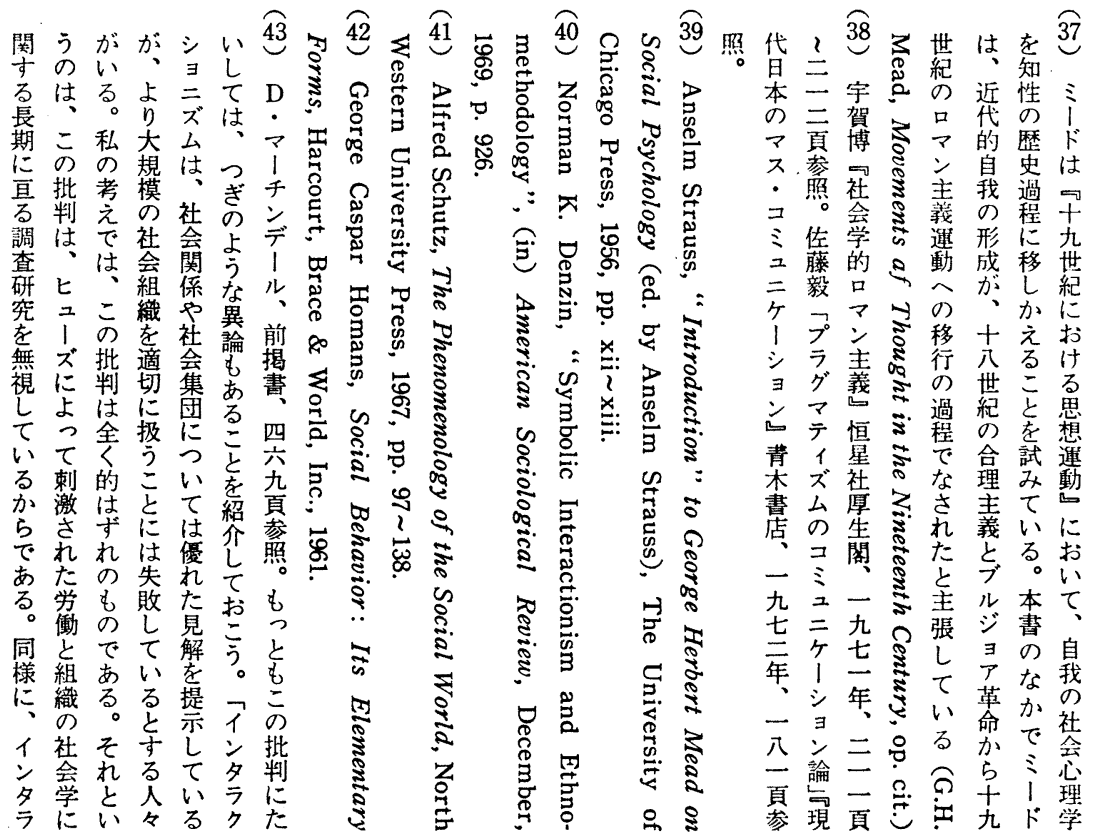



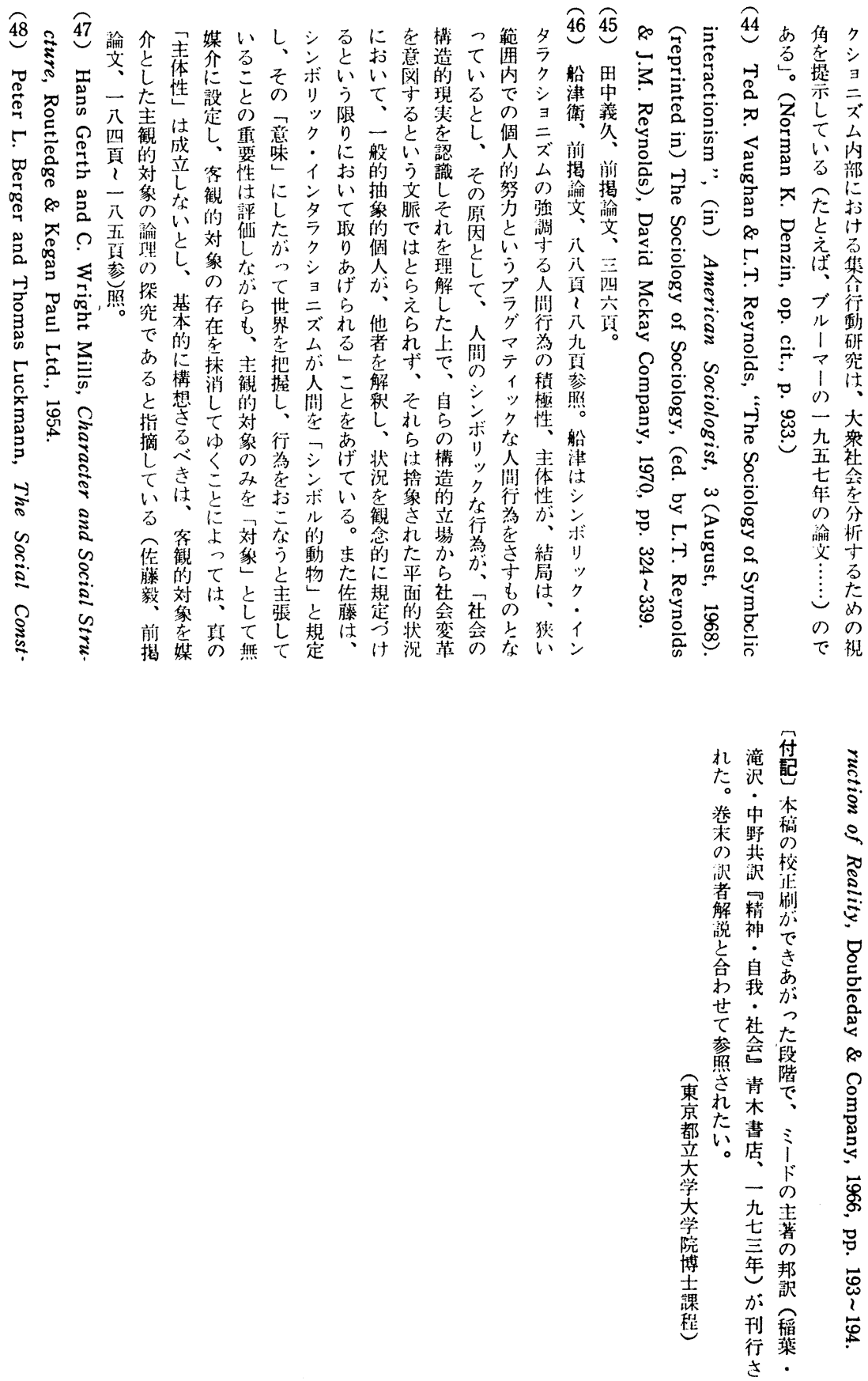


\section{G.H. Mead and Symbolic Interactionism}

\section{Tadamasa Murai \\ Tokyo Metropolitan University}

Today sociology, which as originally founded as a science of social crises in the early nineteenth century Europe, seems to have been too much institutionalized. In the second half of 1960s many young American sociologists began to question the basic assumptions of so called "established sociology ", particularly that of Parsonian "Grand Theory" of structural-functional analysis and "Abstracted Empiricism" in terms of the late C.W. Mills. Thus there is no doubt that the critical traditions of the discipline have found its new partisans in recent years.

In spite of this growing split between "establishment sociology" and "radical sociology", the mainstream of the discipline is still in the safe and shallow waters of academic empricism. Nonetheless there is a new trend which seems to be of great importance for the future of sociology; the rise of a new interest in the symbolic interactionism of George Herbert Mead.

The growing interest in details of social interaction, in the structure of the worlds of our everyday life, is likely to take us back to Mead again. With the recent decline of functionalism, Mead's thought has begun to attract deep concern of younger sociologists.

In 1966 Herbert Blumer, the foremost sociological student of Mead, tried to suggest "the freshness, the fecundity, and the revolutionary implications" of Mead's point of view. In the essay, which developed into a serial of polemics, Blumer stressed that Mead had seen the self as a dynamic process of interaction between "I" and "Me".

However, Mead's treatment of the self as a process was transformed into something much more static and his "generalized other" became just another way of talking about reference group.

In this article the author makes some critical appraisals of the key concepts of Mead's self theory and then he considers if symbolic interactionism could be a more appropriate methodology for the study of human behavior than the positivistic methods which were borrowed from the natural sciences. 